\title{
Do Government Benefits Affect Officeholders' Electoral Fortunes? Evidence from State Earned Income Tax Credits*
}

\author{
Hunter E. Rendleman ${ }^{\dagger}$ \\ Department of Government \\ Harvard University \\ Jesse Yoder ${ }^{\ddagger}$ \\ Department of Political Science \\ Stanford University
}

May 13, 2020

\begin{abstract}
Whether and how individuals link benefits they receive from the government to their voting behavior is a central question in political economy. We study this question using one of the largest social provision programs in the United States: The Earned Income Tax Credit (EITC). We exploit the staggered roll-out of state-level EITC programs to estimate the causal effect of the program on elections, voter behavior, and attitudes about the government. Contrary to predictions from the policy feedback literature, we show that the credit leads to higher vote shares and approval ratings for the implementing governor. These effects are temporally limited to the first years of the credit's availability, and dissipate over time. Taken together, our results suggest that voters are responsive to the benefit.
\end{abstract}

Key Words: Tax policy, state taxes, economic voting, policy feedback

\footnotetext{
*Authors are listed in alphabetical order and contributed equally. For helpful comments and suggestions, the authors thank Matt Blackwell, Jacob Brown, Claudine Gay, Andy Hall, Vlad Kogan, Shiro Kuriwaki, Tyler Simko, Dan Thompson, Soichiro Yamauchi, Michael Zoorob, and workshop participants at Harvard University.

${ }^{\dagger}$ Hunter E. Rendleman is a Ph.D. Student in the Department of Government at Harvard University (hrendleman@g.harvard.edu; 1737 Cambridge St, Cambridge, MA 02138).

${ }^{\ddagger}$ Jesse Yoder is a Ph.D. Candidate in the Department of Political Science at Stanford University (yoderj@stanford.edu; 616 Serra Mall, Stanford, CA 94305).
} 
"I was like, 'Oh my God, I can't believe this is the money we're going to get!' We can do so much."

\section{—Bakersfield, CA resident after receiving her tax refund ${ }^{1}$}

"Voters are not fools."

- V.O. Key, The Responsible Electorate

\section{Introduction}

One of the longest running literatures in political economy explores the extent to which voters use their economic well-being as a metric to evaluate incumbent performance. Scholars in the tradition of Key (1966) have argued that voters respond to changes in economic performance like GDP growth (Kramer 1971; Fair 1978); local wages and employment (de BenedictisKessner and Warshaw 2019); gas prices (Ansolabehere, Meredith, and Snowberg 2014); as well as more particularistic policy changes like trade adjustment assistance (Margalit 2011), health insurance (Clinton and Sances 2018), and welfare benefits (Kogan 2019). Examining the political effects of these particularistic economic policies is important because they might create new constituencies, or at least more invested ones, who in turn influence electoral politics and other policymaking. ${ }^{2}$

In this paper, we estimate the causal effect of the one of the largest social provision programs in the United States - the Earned Income Tax Credit (EITC) - on election outcomes, political attitudes, and participation. According to the Center on Budget and Policy Priorities, the EITC lifted about 5.7 million people out of poverty in 2017 alone, ${ }^{3}$ and has been hailed as the "best anti-poverty, best pro-family, best job creation measure to come out of Congress." 4 An ever-growing body of research shows that the introduction of EITC

\footnotetext{
${ }_{1}$ https://calmatters.org/poverty/california-divide/2019/ 06/tax-credit-working-poorcalifornia-eitc-newsom/

${ }^{2}$ Perhaps the most pertinent example of an economic policy creating newly invested, highly motivated constituencies was the creation of the Social Security program (Campbell 2003).

${ }^{3}$ https : //www . cbpp.org/research/federal-tax/policy-basics-the-earned-income-tax-credit

${ }^{4}$ President Ronald Reagan, Radio Address to the Nation on Tax Reform
} 
programs is associated with increased financial security and happiness, as well as a variety of physical and mental health outcomes. ${ }^{5}$

The program's effects on election outcomes, voter behavior, and attitudes about the government remain an open question. To estimate the political effects of the EITC, we leverage the fact that, in recent years, states opted to introduce their own versions of the EITC. This refundable tax credit, first rolled out at the federal level in 1975, has been expanded by 29 states as a means to reduce poverty through a directed transfer to working tax payers, particularly those with children. Using a series of difference-in-differences designs that exploits variation in states' differential adoption timing of EITC programs from 19922018, we find that state EITC laws do not have large overall effects on gubernatorial elections. However, this finding does not mean that voters' behaviors are unresponsive to receiving targeted benefits from the government. In follow-up analyses, we show that Governors are rewarded electorally in the year after they implement an EITC program, but these effects dissipate over time. We show that these effects are concentrated in counties where the EITC was implemented by a Republican governor and where many voters received the benefit, suggesting that low-income voters reward the Republican party for implementing programs where they benefit. This finding is robust to a variety of alternative explanations for the observed effect.

Because the earned income tax credit has clear and observable eligibility requirements, we can learn more about the effects of the EITC on individuals who qualify for the refund. Using a time-series cross-sectional design with data from the Cooperative Congressional Election Study (CCES), we find that eligible individuals increase their support for the governor in the filing season after they first receive the benefit. Moreover, eligible individuals in areas where more people claim the credit particularly increase their support for the governor.

\footnotetext{
${ }^{5}$ For example, previous work shows that the EITC reduces depression and increases happiness (Boyd-Swan et al. 2016), reduces maternal smoking (Averett and Wang 2013), leads to increased self-reported physical and mental health among eligible mothers (Evans and Garthwaite 2014), increases health insurance coverage (Baughman 2005; Baughman and Duchovny 2016; Hoynes, Miller, and Simon 2015; Lenhart 2019), improves infant health (Markowitz et al. 2017), and reduces behavioral problems among children (Hamad and Rehkopf 2016).
} 
Beneficiaries of the EITC do not change their approval of other federal-level officeholders, nor do they have greater confidence in the performance of the economy. Overall, these results suggest that voters are responsive to receiving targeted benefits, and they seem to be able to map the source of their windfall to the state as opposed to the national government.

Taken together, the results show that voters who benefit from EITC programs respond in a way consistent with their economic incentives by increasing their support for the officeholders responsible for enacting the policy. There are a few reasons why this type of voter responsiveness to the economic policies of their elected officials is not necessarily guaranteed. First, if candidates of opposing parties offer similar economic policies, individual beneficiaries might not change their preferences in response to receiving economic benefits (Stigler 1973; Ashworth and Bueno De Mesquita 2014; Hall, Yoder, and Karandikar 2019). The partisan balance of those responsible for adopting state EITC programs is relatively balanced, which raises the possibility that voters might not be able to distinguish which party is responsible for providing the benefit they receive. In this case, voters might lack information to assign responsibility for policy to particular public official or level of government (Arceneaux 2006; Rogers 2017). ${ }^{6}$ Second, and perhaps relatedly, increasingly "nationalized" voting behavior in the United States might mean that voters no longer separate state and local policies from federal ones (Hopkins 2018). We show that state EITC programs lead to increased support for governors - the officeholders responsible for enacting the program - among eligible individuals, while they do not lead to increased support for other officeholders that do not implement the program, like Presidents or Congressional representatives. This suggests that individuals are mapping the benefits they receive from the government to the level of government that provides the benefit. Third, partisanship might bias voters' perceptions of changes in their economic circumstances and prevent them from attributing policies to the elected officials that enacted them (e.g., Campbell et al. 1960; Green, Palmquist, and

\footnotetext{
${ }^{6}$ Relatedly, a variety of studies seek to link voting behavior to economic fortunes and other events, that are clearly outside of the control of elected officials (e.g., Healy, Malhotra, and Mo 2010; Achen and Bartels 2016).
} 
Schickler 2004; Achen and Bartels 2016). ${ }^{7}$ Our results suggest that bling partisanship cannot completely explain voters' preferences.

Our results are also in conversation with the policy feedback literature. While the idea that new policies create a new politics goes back to Schattschneider et al. (1935), the literature interrogating this claim is relatively young (e.g., Campbell 2003; Lerman and McCabe 2017; Michener 2017; Clinton and Sances 2018; Feigenbaum, Hertel-Fernandez, and Williamson 2019). Some hypothesize that policies that are difficult to trace back to government action are least likely to generate feedback effects in the mass public (Tufte 1978; Kettl 1988; Arnold 1990). Tax credits like the EITC, transferred to their tax refund, are described by Mettler (2011) as being part of the submerged state: a set of government policies that remain hidden from the general public. At first glance, our results may seem at odds with recent work documenting a weak, at times negative relationship between EITC-beneficiary status and attitudes towards the government (e.g., Mettler 2011; Halpern-Meekin et al. 2015; Shanks-Booth and Mettler 2019). Instead, we view our results as expansionary: through the use of a causal design and several years' worth of data we observe that the positive electoral and attitudinal effect of the state EITC is temporally limited, suggesting that before policies are submerged, there is a chance they can shape the political environment they are deployed in.

This paper also helps to reconcile two seemingly competing ideas: that policies like the EITC might have small overall effects on political outcomes but that voters are simultaneously quite responsive to these policies. The enactment of EITC programs do not have large and systematic effects on elections overall: our county-level analyses show that Republican governors might be rewarded in the short term for implementing these programs, but that these effects quickly dissipate over time. However, our individual-level results show that the small overall effects on election outcomes do not necessarily imply that voters are

${ }^{7}$ Overall, this behavioral school would suggest that voters form relatively stable partisan identities and spend little time considering how their economic incentives map to their support for candidates. 
ill-equipped to map the benefits of the policy onto the officeholders responsible, or that partisanship prevents them from updating their approval of officeholders.

This paper is organized as follows. Section 2 details our identification strategy and data. Section 3 presents estimates from a difference-in-differences model using county-level electoral returns data for the period 2002-2018. Section 4 uses individual-level survey data for the period 2008-2016 to disentangle the effect of the EITC on eligible versus ineligible voters. Finally, section 5 considers the implications of our estimates and concludes.

\section{Studying How the Earned Income Tax Credit Affects Elections}

The EITC has been implemented at the federal, state, and municipal level as a means to support low to moderate-income recipients, particularly those with children. The credit was first enacted at the federal level in 1975, and expanded in the 1980s, 1990s, and 2000s. It is characterized by its phase-in and -out design: households receive a refundable credit equal to a percentage of their earnings up to a maximum credit and then the credit remains flat until earnings reach the phaseout point. ${ }^{8}$ Since 1994 the credit has been available to all low-income workers, though workers with qualifying children receive a much larger credit (at most $\$ 6,431$ in tax year 2018) than those without (at most $\$ 519$ in tax year 2018). ${ }^{9}$

Figure 1 shows the proportion of returns in each county that claimed the EITC in 2016. These counties tend to be concentrated in the South, are more rural, have larger nonwhite populations, and have lower per capita incomes. In Section A.1.2 of the Appendix, we summarize the features of EITC claimers compared to the overall adult population. Recipients of the EITC are more likely to be female, nonwhite, single, and have about

\footnotetext{
${ }^{8}$ Refundable in this case means that if a credit exceeds a taxpayer's state income tax, the taxpayer receives the excess amount as a payment from the state.

${ }^{9}$ A qualifying child is determined by a given child's relationship to the beneficiary, their age, and where they live.
} 


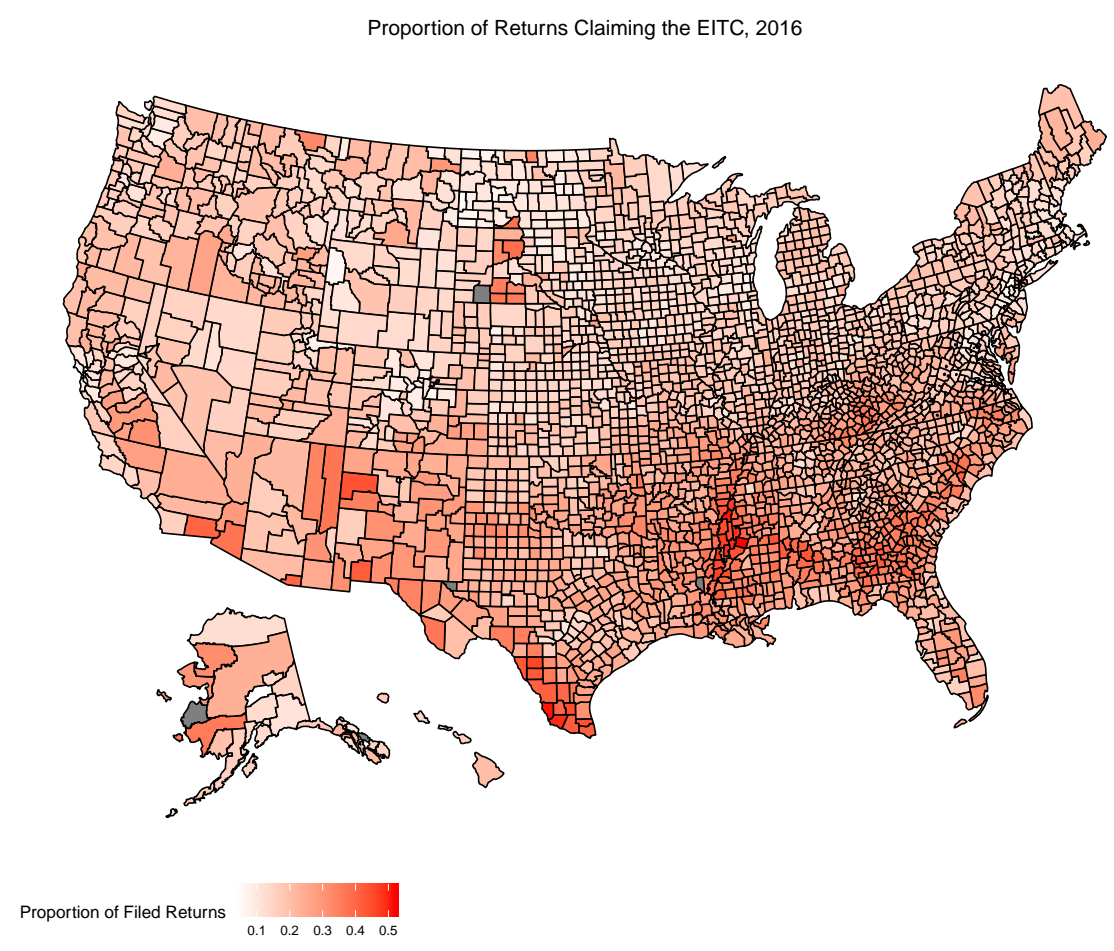

Figure 1 - Proportion of Returns Claiming the EITC in 2016

Darker colors indicate a higher proportion of returns claiming the EITC in 2016.

Dark grey indicates a lack of IRS data.

one more child than non-recipients, on average. ${ }^{10}$ They are also less likely to report being employed and are more likely to receive Supplemental Nutrition Assistance Program (SNAP) benefits. $^{11}$

\section{EITC Expansion at the State Level}

To study the effect of the EITC on political outcomes, we rely on state-level EITC expansions from 1992-2018. During this period, 22 states implemented some form of an earned income

\footnotetext{
${ }^{10}$ For a good summary on the characteristics of individuals who claim the EITC, also see Liebman (2000).

${ }^{11}$ Recipients need not earn income themselves to qualify for the credit, as it is allocated to households as defined by filing status. The IRS estimates that between 21 percent and 26 percent of EITC claims are paid in error. Typically, these mistaken claims are a result of multiple filers claiming the same dependent children (https://www.eitc.irs.gov/tax-preparer-toolkit/frequently-asked-questions/fraud) .
} 
tax credit. ${ }^{12}$ Most states have credits that mirror the phase-in, phase-out design of the federal credit and provide eligible tax payers with some percentage of their federal EITC benefit. For example, Massachusetts provides a credit to eligible households equal to 23 percent of the federal EITC. Table 1 describes the state EITCs as of 2018, and it also shows that the partisanship of the enacting governors in our period of study is relatively balanced. At the time of their state's adoption (or re-adoption) of the EITC, 13 governors were Republican, 1 was an Independent, and 13 were Democrats. Figure 2 shows the temporal distribution of state EITC adoption, which is the main source of variation we exploit in this study. ${ }^{13}$

\section{Assembling the County-Level Dataset}

To study how the state EITC affects elections, we code the information summarized in Table 1 to generate a state-year dataset of whether a state had an EITC in place in each year along with the party of the Governor when the EITC was enacted. ${ }^{14}$

The main empirical challenge to estimating the political effects of EITC laws is that there might be factors that both lead to states to adopt EITC and affect gubernatorial elections. For example, states might experience shifts in public opinion that favor providing more benefits to low-income families - resulting in both the enactment of an EITC program and a shift toward electing Democratic governors. To address this potential source of bias, we assemble a county-level panel, which is the smallest available level of aggregation for which we can measure election returns for our study period. ${ }^{15}$ By doing so, we can estimate the effects looking only at similar counties or counties within the same region. We also match

${ }^{12}$ North Carolina abolished its EITC after the 2013 tax season after establishing it 5 years prior in 2008. As of 2016, of the states with an EITC, 3 states had nonrefundable credits: Delaware, Ohio, and Virginia. Because we lack election data prior to 1990, states that adopted their own EITC before 1990 (Maryland, Rhode Island, Vermont, and Wisconsin) do not ultimately enter our analysis.

${ }^{13}$ Figure A.1 in the Appendix shows the geographic distribution of state EITCs as of 2016. Most of the states that adopt a refundable state EITC are in the Northeast and Midwest, along with a few states in the West like California and Oregon.

${ }^{14}$ We also code whether the EITC in that year came in the form of a refundable credit and its percentage of the federal EITC (See https://users.nber.org/ taxsim/state-eitc.html).

${ }^{15}$ The empirical approach is similar in nature to Feigenbaum, Hertel-Fernandez, and Williamson (2019), which has a state-level treatment (Right-to-Work Laws) but uses county-year as the unit of analysis in order to estimate effects on elections using similar counties. 
Table 1 - Description of State Earned Income Tax Credits as of 2018.

\begin{tabular}{|c|c|c|c|c|c|}
\hline State & $\begin{array}{c}\text { Year } \\
\text { enacted }\end{array}$ & $\begin{array}{c}\text { Governor } \\
\text { at time of enactment }\end{array}$ & $\begin{array}{c}\text { Party } \\
\text { of Governor }\end{array}$ & Refundable & $\begin{array}{l}\text { Percentage of } \\
\text { federal EITC }\end{array}$ \\
\hline California & 2015 & Brown & $\mathrm{D}$ & Yes & $\begin{array}{l}85 \text { percent of the federal credit, } \\
\text { up to half of the federal phase-in }\end{array}$ \\
\hline Colorado & $1999 ; 2015$ & Romer; Hickenlooper & $\mathrm{D}$ & Yes & 10 percent \\
\hline Connecticut & 2011 & Malloy & $\mathrm{D}$ & Yes & 27.5 percent \\
\hline Delaware & 2006 & Miner & $\mathrm{D}$ & No & 20 percent \\
\hline District of Columbia & 2000 & Williams & $\mathrm{D}$ & Yes & 40 percent \\
\hline Illinois & 2000 & Ryan & $\mathrm{R}$ & Yes & 10 percent \\
\hline Indiana & 1999 & O'Bannon & $\mathrm{D}$ & Yes & 9 percent \\
\hline Iowa & 1990 & Branstad & $\mathrm{R}$ & Yes & 15 percent \\
\hline Kansas & 1998 & Graves & $\mathrm{R}$ & Yes & 17 percent \\
\hline Louisiana & 2008 & Jindal & $\mathrm{R}$ & Yes & 3.5 percent \\
\hline Maine & 2000 & King & I & Yes (as of 2016) & 5 percent \\
\hline Maryland & 1988 & Schaefer & $\mathrm{D}$ & Yes & $\begin{array}{l}\text { Refundable: } 25 \text {; } \\
\text { nonrefundable } 50\end{array}$ \\
\hline Massachusetts & 1997 & Weld & $\mathrm{R}$ & Yes & 23 percent \\
\hline Michigan & 2008; 2012 & Granholm; Snyder & $\mathrm{D} ; \mathrm{R}$ & Yes & 6 percent \\
\hline Minnesota & 1992 & Carlson & $\mathrm{R}$ & Yes & Varies \\
\hline Nebraska & 2006 & Heineman & $\mathrm{R}$ & Yes & 10 percent \\
\hline New Jersey & 2000 & Whitman & $\mathrm{R}$ & Yes & 35 percent \\
\hline New Mexico & 1994 & Richardson & $\mathrm{D}$ & Yes & 10 percent \\
\hline New York & 1994 & Cuomo & $\mathrm{D}$ & Yes & 30 percent \\
\hline North Carolina & 2008 & Easley & $\mathrm{D}$ & Yes & 5 percent \\
\hline Ohio & 2013 & Kasich & $\mathrm{R}$ & No & $\begin{array}{c}10 \text { percent, limited to } 50 \text { percent } \\
\text { of liability for Ohio Taxable Income } \\
\text { over } \$ 20,000\end{array}$ \\
\hline Oklahoma & 2002 & Keatinig & $\mathrm{R}$ & Yes & 5 percent \\
\hline Oregon & 1997 & Kitzhaber & $\mathrm{D}$ & Yes & 8 percent \\
\hline Rhode Island & 1986 & DiPrete & $\mathrm{R}$ & Yes (as of 2015) & 12.5 percent \\
\hline Vermont & 1988 & Kunin & $\mathrm{D}$ & Yes & 32 percet \\
\hline Virginia & 2006 & Warner & $\mathrm{D}$ & No & 20 percent \\
\hline Wisconsin & 1989 & Thompsonn & $\mathrm{R}$ & Yes & $\begin{array}{l}4 \text { percent for families with one child; } \\
11 \text { for families with two children; } \\
34 \text { for families with three or more children }\end{array}$ \\
\hline
\end{tabular}

counties directly based on their pre-treatment political trends, so that we make comparisons only within counties on similar political trajectories before one of them implemented an EITC program.

The county-level panel also offers another advantage. Counties experience different levels of "exposure" to the introduction of the state EITC. We merge the state EITC treatment variable to county-level information on the proportion of tax filers who claim the EITC, provided by the IRS's Statistics of Income program. We use the proportion of EITC claimers in a county to measure a county's exposure to the treatment: that is, the fraction of tax filers we can expect to see a refundable credit from the state when the state implements its 


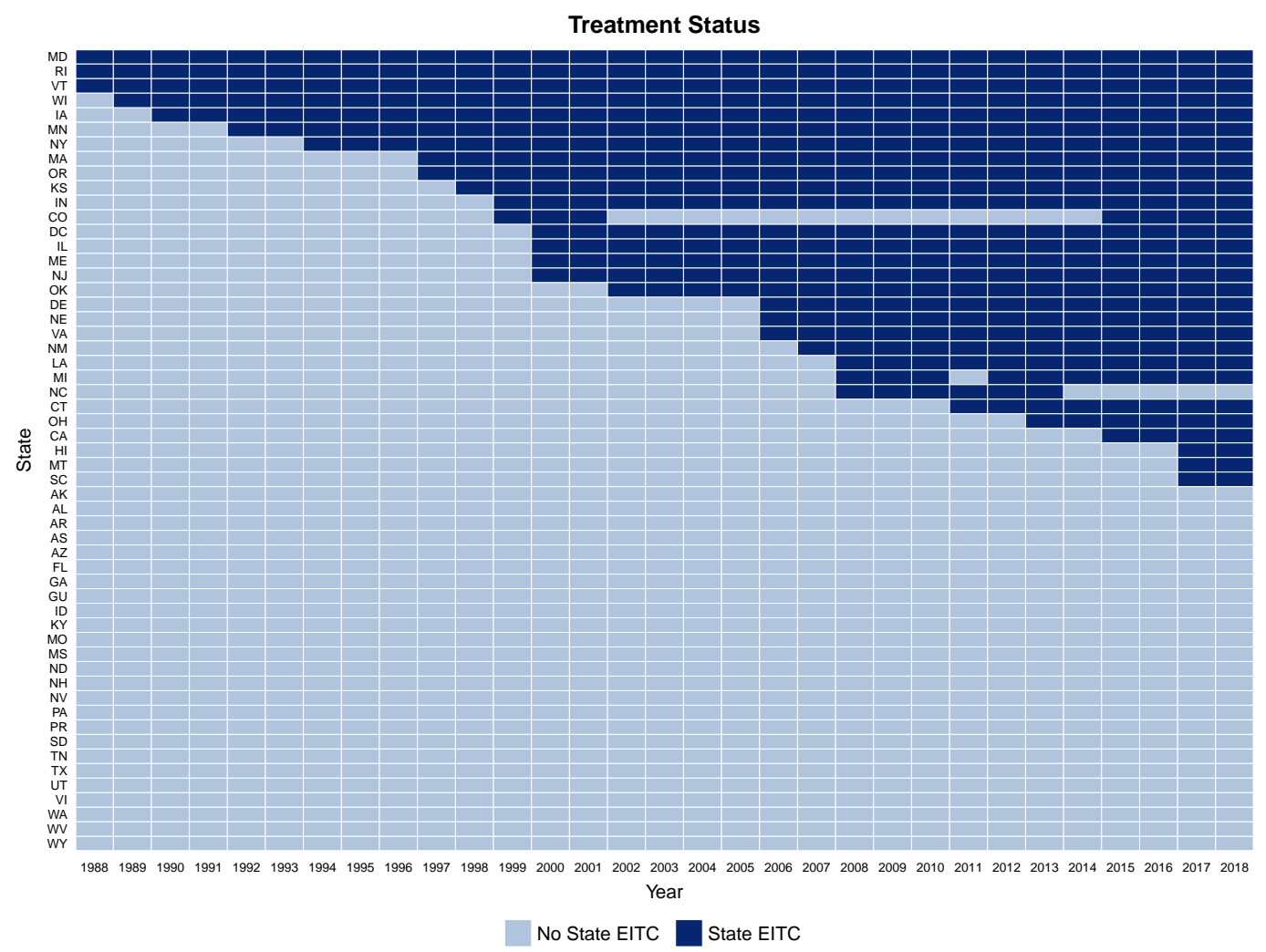

Figure 2 - State EITC Adoption Timeline The horizontal axis plot each year, and the vertical axis indicates each state. Dark blue squares indicate that a state had its own EITC program in that year, while light blue squares indicate the state did not have an EITC program in place.

EITC. In 2016, the average county's proportion of returns claiming the EITC was 19.2\%.16

We merge each county-year observation to vote shares for Governor in that county-year. ${ }^{17}$

We also include information about the county population and turnout rate in each year. ${ }^{18}$

\footnotetext{
${ }^{16}$ This ranged from about $5.6 \%$ to $37.8 \%$. The geographic variation in this exposure measure is summarized in Figure 1. We find that state-level EITC programs have no effects on the program's uptake, as measured by the fraction of tax returns claiming the EITC. This is consistent with recent evidence that EITC programs have little to no impact on labor supply at the extensive margin (Kleven 2019).

${ }^{17}$ The county-level election data for Gubernatorial races come from Dave Leip's Atlas of Presidential Elections for 1990-2014. For 2015-2018, we collect county-level election returns for Gubernatorial races from the New York Times election results.

${ }^{18}$ County population comes from the US Census, and we linearly interpolate population for non-Census years. Turnout rate is measured as the total number of votes in the county divided by the county population.
} 


\section{Assembling the Individual-Level Dataset}

To understand how individual attitudes change after a state adopts an EITC program, we use pooled cross-sectional data from the Cooperative Congressional Election Study (CCES) from 2008-2016. We merge respondents to the state-level EITC treatment and countylevel exposure measures described above. With this individual-level data in hand, we can determine whether a respondent is eligible to receive the EITC for a given filing season by using data on their reported income, marital status, and number of children. Requirements largely remain constant over time, and we use the lower bound of income brackets in the CCES to code EITC eligibility. Our analysis, therefore, likely underestimates the number of eligible individuals surveyed in the CCES. To the extent that eligible respondents are coded as ineligible, this would likely attenuate the effects of EITC eligibility in our analyses. ${ }^{19}$

\section{Overall Non-Effects of State EITC Programs on Elec- tions}

We first estimate the effect of state EITCs on the Democratic vote share for Governor at the county level. We estimate the following equation:

$$
\text { Dem Vote Pct } \text { cst }=\alpha E I T C_{s t}+\beta\left(E I T C_{s t} * \text { Implemented by Democrat }_{s}\right)+\gamma_{c}+\delta_{t}+\epsilon_{c s t},
$$

where Dem Vote Pct cst is the two-party Democratic vote share for Governor in county $c$ and state $s$ in election year $t$, which runs from a minimum of 0 to a maximum of 1 . The variable $E I T C_{s t}$, takes a value of 1 for whether a state EITC was implemented in election year $t$ and 0 otherwise, while Implemented by Democrat Dis $_{1}$ for if a Democratic Governor enacted the

\footnotetext{
${ }^{19}$ To validate our measure of EITC receipt, in Table A.1 in the Appendix we compare EITC-eligible and ineligible respondents in the CCES, along with EITC recipients and non-recipients from the ASES. Table A.2 compares EITC-eligible respondents in the CCES with those who report actually receiving the EITC in the ASEC. Our sample of potential EITC recipients in the CCES is more likely to be female, single, Black, and younger than EITC recipients in the ASES. Our eligible individuals also have more children than actual recipients, are less likely to be employed, and are more educated, on average.
} 
EITC, and -1 if a Republican Governor enacted the EITC. ${ }^{20}$ The terms $\gamma_{c}$ and $\delta_{t}$ represent county and year fixed effects, respectively. The treatment effect of interest, then, is $\beta$, which measures the extent to which the EITC-implementing party is rewarded after it adopts the state EITC program.

The direction of the effect is not obvious ex ante. As we show in Table 1, the party affiliation of governors who have enacted state EITCs over time is relatively balanced. In Table 2, we estimate the effect of implementing the EITC on Democratic vote share using five different specifications, and we weight each of the estimates by county population. In the first column, we use county and year fixed effects, and we do not find evidence of an increase in the Democratic vote share for Governor in counties where a Democrat was responsible for enacting the EITC program. The $95 \%$ confidence interval on the interaction term ranges from about -4.2 to +2.9 percentage points. The standard deviation of the county-demeaned governor vote share is about 10.9 percentage points, so we can comfortably rule out effect sizes of more than about $1 / 2$ of a standard deviation.

The analysis is a difference-in-differences design in which we compare within-county changes in the Democratic Governor's vote share over time across within-county changes in whether that county had a state EITC program. To interpret this estimate as causal, it must be the case that, in the absence of the treatment, counties in states that adopt state EITC programs would have had similar trends in Democratic vote shares as counties in states that did not adopt state EITC programs. One way to relax this parallel trends assumption is the alter the time fixed effects in a variety of ways in order to change the implied counterfactual comparisons. We do this in columns 2 through 6 of Table 2, and the results remain substantively similar, suggesting that the parallel trends assumption might hold.

In column 2, we assign each county to a separate decile based on its population in the 1990 Census and construct a set population decile-by-year fixed effects. Implicitly, this design

\footnotetext{
${ }^{20}$ Maine is dropped from the analysis because Angus King (I) was governor at the time of adoption.
} 
Table 2 - Effects of State EITC Expansion on Implementing Governor Performance, County Level, 1990-2018.

\begin{tabular}{|c|c|c|c|c|c|c|}
\hline & \multicolumn{6}{|c|}{ Dem Gov Vote Pct (0-1) } \\
\hline & $(1)$ & $(2)$ & $(3)$ & $(4)$ & $(5)$ & $(6)$ \\
\hline State EITC & $\begin{array}{l}-0.01 \\
(0.02)\end{array}$ & $\begin{array}{l}-0.01 \\
(0.02)\end{array}$ & $\begin{array}{c}-0.01 \\
(0.02)\end{array}$ & $\begin{array}{l}-0.01 \\
(0.02)\end{array}$ & $\begin{array}{l}-0.02 \\
(0.02)\end{array}$ & $\begin{array}{c}0.02 \\
(0.02)\end{array}$ \\
\hline State EITC $\times$ Dem Gov. Implemented & $\begin{array}{l}-0.01 \\
(0.02)\end{array}$ & $\begin{array}{l}-0.02 \\
(0.01)\end{array}$ & $\begin{array}{c}0.00 \\
(0.01)\end{array}$ & $\begin{array}{l}-0.01 \\
(0.02)\end{array}$ & $\begin{array}{c}0.01 \\
(0.02)\end{array}$ & $\begin{array}{r}-0.01 \\
(0.02)\end{array}$ \\
\hline $\mathrm{N}$ & 23,875 & 23,875 & 23,875 & 23,606 & 14,312 & 12,576 \\
\hline County FEs & $\sqrt{ }$ & $\sqrt{ }$ & $\sqrt{ }$ & $\sqrt{ }$ & $\sqrt{ }$ & $\sqrt{ }$ \\
\hline Year FEs & $\sqrt{ }$ & & & & & \\
\hline Pop Decile-Year FEs & & $\sqrt{ }$ & & & & \\
\hline Census Division-Year FEs & & & $\sqrt{ }$ & & & \\
\hline EITC Exposure Decile-Year FEs & & & & $\sqrt{ }$ & & \\
\hline Pre-Trend Match-Year FEs & & & & & $\sqrt{ }$ & \\
\hline Border Pair-Year FEs & & & & & & $\sqrt{ }$ \\
\hline
\end{tabular}

Robust standard errors clustered by state in parentheses in columns 1-5. Robust standard errors clustered two-way by state and border-pair in column 6. Dem Party Inc is 1 for Dem, - 1 for Rep. Implementing Dem Gov is 1 for Dem, -1 for Rep. All regressions apply county population weights.

estimates a separate difference-in-differences within each population decile and averages the estimates together. Put another way, in this specification we only construct counterfactual comparisons for treated counties using control counties that have a similar population. The estimate grows slightly more negative to nearly -2 percentage points, which is substantively similar to column 1, and the sign is in the opposite direction of what we would predict if counties reward Governors for enacting EITC programs. In column 3, we construct Census Division-by-year fixed effects, so that we only make comparisons among counties within the same region. ${ }^{21}$ Again, the results are similar. Taken together, these first three columns show that governors do not seem to be rewarded electorally for implementing EITC programs.

These results, however, still might be biased if the fixed effects do not generate comparisons among counties with parallel trends. Columns 2 and 3 of Table 2 might make the parallel trends assumption more plausible, but we can still try to estimate the same regres-

${ }^{21}$ See https://www2.census.gov/geo/pdfs/maps-data/maps/reference/us_regdiv.pdf. 
sion after matching on pre-treatment trends directly. To do so, in column 5 of Table 2 we implement we implement a matching procedure similar to Imai, King, and Nall (2009) and Thompson (2019) in order to generate matched pairs of counties that exhibit the best possible match on pre-treatment trends. ${ }^{22}$ We interact year fixed effects with pre-trend matched pairs, exploiting only the variation within matched pairs over time. The results using this approach, shown in column 5 of Table 2, are substantively similar to the results in other specifications, again suggesting that governors do not seem to be rewarded for implementing EITC programs.

Finally, following Feigenbaum, Hertel-Fernandez, and Williamson (2019) we implement a border pair design, where we limit the sample to pairs of counties on either side of a state EITC border between 1990 and 2018. ${ }^{23}$ Specifically, we estimate the following equation:

$$
\text { Dem Vote Pct } t_{c s p t}=\alpha E I T C_{s t}+\beta\left(\text { EITC }_{s t} * \text { Implemented by Democrat }_{s}\right)+\gamma_{c}+\delta_{p t}+\epsilon_{c s p t},
$$

where $\delta_{p t}$ represent border pair by year fixed effects. This border pair design assumes that across-border counties in states that do not implement EITC programs provide valid counterfactual trends for counties in states that do implement EITC programs. The results, from this border-pair design, shown in column 6 of Table 2, are again very similar. Overall, governors do not seem to reap long-term electoral rewards from implementing state EITC programs.

The overall non-effect from Table 2, however, could be masking important dynamics of the EITC's effect. Next, we explore a few important dimensions of heterogeneity in the effect

\footnotetext{
${ }^{22}$ Specifically, for every treated unit, we calculate the squared distance in Democratic vote share for governor in every period prior to EITC implementation for every possible control unit. We weight these squared distances according to the following equation: $w=(y-1990)^{2} /($ treatment year -1990$)$, where $w$ is the weight, $y$ is the year, 1990 is the first year in the Governor election panel, and treatment year is the first year where the treated county is treated. This weight penalizes large distances in the vote share between the treated and control units more heavily when the year is closer to the time when the treated county enacts the EITC program. For each treated county, we match them to a county that was never treated that minimizes this the mean squared distance in pre-treatment vote shares.

${ }^{23}$ To generate comparable matched pairs, we limit the analysis to border pairs where both states are on the same gubernatorial electoral cycles.
} 
size based on 1) which counties are most affected by the program, 2) which party implements the program, and 3) the timing of the program's implementation.

\section{Counties Reward Republican Governors for Implementing EITCs}

First, the lack of an overall benefit of state EITC programs for enacting governors could be a result of county competition over the program's benefits. When a state implements an EITC program, it could be that counties in the state that benefit the most from the state EITC program reward enacting governor, while the counties that benefit the least choose to punish the enacting governor.

To test this explanation, we measure each county's exposure to the EITC program, defined as the proportion of tax filers in 2004 who claimed the federal EITC. ${ }^{24}$ We bin these counties into two groups to create an indicator variable, High Exposure ${ }_{c}$, for whether the county falls above the median in terms of its exposure to the EITC program. We interact this with the state EITC treatment and with the party of the governor responsible for enacting the program. Figure 3 shows the effect of state EITC programs on Democratic vote share for Governor by exposure and by enacting Governor party. ${ }^{25}$ It shows that EITC programs lead to a decline in Democratic vote share in counties where both a Republican implements the program and many individuals in the county benefit from the program. The decline in Democratic vote share in high exposure counties where a Republican Governor enacts the EITC is large - about 7.9 percentage points, with the $95 \%$ confidence interval ranging from about -12.0 to -3.8 percentage points. This result is consistent with an interpretation where the program's beneficiaries reward Republican governors for implementing a state EITC program. Democratic Governors who enact EITC programs do not seem to reap similar electoral rewards, even in high exposure counties. One possible explanation for this is that

\footnotetext{
${ }^{24}$ The county-level IRS data on the proportion of tax filers who claim the EITC begins in 2004, so to avoid post-treatment bias we subset our analyses to include only 2002-2018, where the relevant variation to identify the treatment effect, EITC program within county, comes on or after 2004.

${ }^{25}$ Table A.5 shows the full results. We use our preferred specification, column 4 of Table A.5, which constructs matched pairs based on the pre-treatment outcome, to construct the coefficient plot in Figure 3.
} 


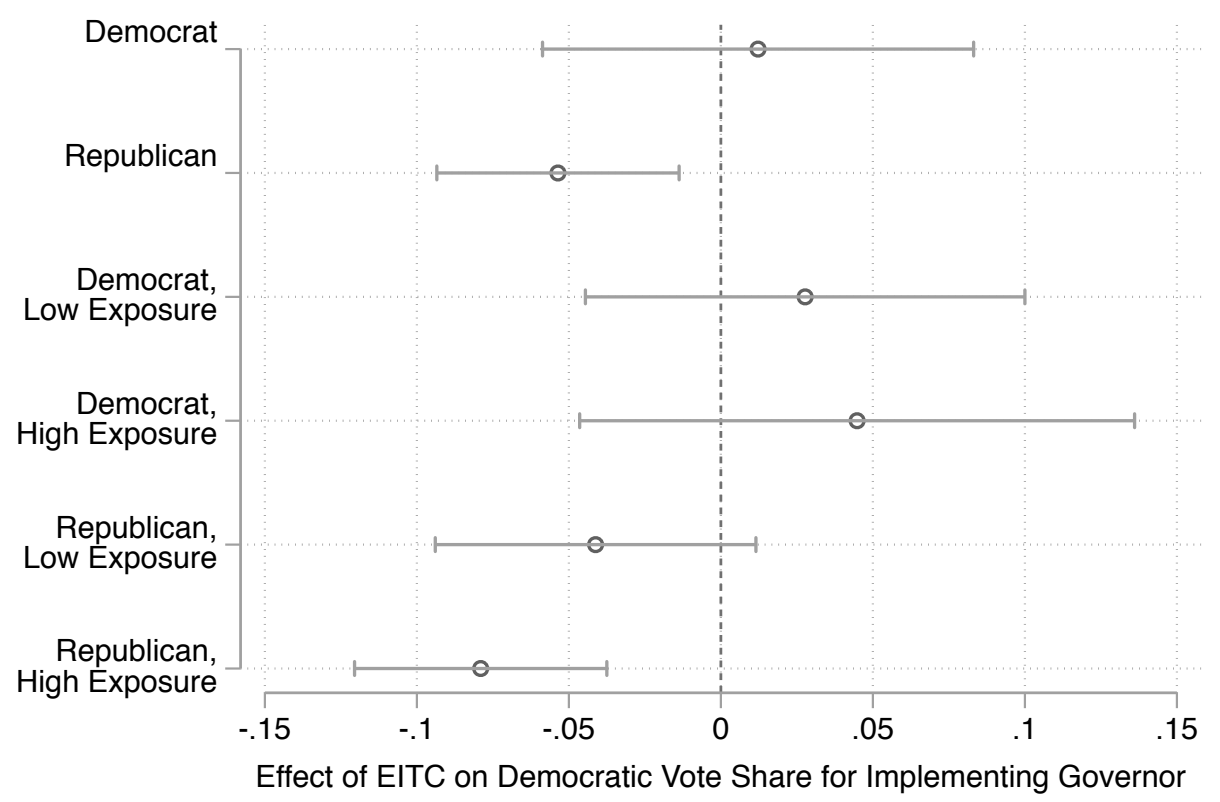

Figure 3 - Effect of State EITC on Democratic Vote Share for Governor, 2002-2018. The horizontal axis shows the treatment effect of state EITC programs on Democratic vote share for Governor, while the vertical axis denotes four different categories for which we estimate treatment effects. Republican and Democrat indicate the party of the Governor who enacted the EITC program, while high and low exposure indicate whether the county is above or below the median proportion of tax filers who claim the EITC. The figure shows that counties reward Republican governors who implement the benefit. The point estimates and $95 \%$ confidence intervals are constructed using robust standard errors clustered by state, using the specification in column 4 of Table A.5.

EITC recipients are more likely to be women, low-income, and have lower education than non-recipients, which are groups who tend support Democrats at high rates (see Table A.1 in the Appendix). If EITC beneficiaries already tend to support Democrats, receiving a benefit from a Democratic Governor might not shift the recipient's beliefs about which party they should support. If a Republican implements the program, however, EITC beneficiaries might update their beliefs in the direction of the Republican party being more likely to provide them with economic benefits. 


\section{The Electoral Effect of the EITC Dissipates Over Time}

So far, the evidence shows that receiving a tax credit from the state government influences a county's election returns for Governor, but that these effects only manifest under certain conditions, e.g., both when a Republican Governor implements the program and where many residents stand to benefit from the tax credit. But do these effects persist over time? Models of party competition and voting behavior would make competing predictions for how tax benefits influence a voter's behavior over time. For example, if voters care solely about what benefits they receive, EITC beneficiaries should increase their support for a party in a way that is constant over time. On the other hand, the electoral benefits for implementing a welfare program might decay over time. This could be, for example, if the benefits are large enough that the opposition party strategically re-positions on the program in the long run, driving the benefits from beneficiaries voting for the enacting party to zero. Or, alternatively, voters might only reward the party in the near term if voters respond only to a change in benefits from one year to the next - for example, if voters notice a large tax refund and receive some psychological boost in the year they notice the increase. ${ }^{26}$ Lastly, the benefits for the enacting governor's party might increase over time. Because individuals might phase in or out of eligibility for the EITC program over time, number of unique individuals that the program has benefited at some point in time will be increasing.

To distinguish between these potential explanations, Figure 4 estimates the dynamic effect of the EITC program. To do so, we take a similar approach as Kogan (2019), generating lags and leads of the EITC's introduction to model the effect flexibly over time. Specifically, we estimate the following equation:

\footnotetext{
${ }^{26}$ A large literature in behavioral economics suggests that individuals receive a psychological boost to seeing a large tax refund (e.g., Mullainathan and Thaler 2000).
} 


$$
\begin{aligned}
\text { DemVoteShare }_{c t}= & \gamma_{c}+\lambda_{t}+\sum_{\tau=0}^{m} \delta_{-t} D_{t-\tau}+\sum_{\tau=0}^{m} \theta_{-t} D_{t-\tau} * \text { Implemented by Democrat }_{c} \\
& +\sum_{\tau=1}^{q} \delta_{+\tau} D_{t+\tau}+\sum_{\tau=1}^{q} \theta_{+\tau} D_{t+\tau} * \text { Implemented by Democrat }_{c}+\epsilon_{c t},
\end{aligned}
$$

where $D$ is the EITC treatment indicator, and the sums on the right-hand side allow for $m$ lags and $q$ leads, or anticipatory effects. On the right-hand side, $\gamma_{i}+\lambda_{t}$ stand in for county and year fixed effects, respectively. The idea here is that future EITC status should not affect rewards for the present governor's vote shares, so each of the $q \theta$ terms should be substantively small. We implement this test with 3 leads of the EITC program, a switching indicator at $t=0$, and 4 lags of the EITC program.

We find that the governor's party might be rewarded in the short term following the introduction of an EITC program. One year following the program's introduction $(\mathrm{t}=1)$, the effect of the program on the enacting governor's vote share is about +9.9 percentage points, with the $95 \%$ confidence interval ranging from 4.6 to 15.3 percentage points. In the years following the program's implementation, the effect goes back to zero, which suggests that the effect of the EITC decays over time. This could be a result of strategic parties re-positioning over time to win over voters, or it could be the result of a psychological effect of noticing a large boost in a voter's tax refund as a result of the program. While the aggregate level data cannot help us distinguish between these possible explanations, in the next section we explore these potential mechanisms using individual-level data from the CCES.

\section{State EITCs Increase Individuals' Approval for Gov- ernors}

So far, we have estimated the effect of state EITC programs on aggregate election outcomes, but how do EITCs affect individuals' attitudes and perceptions about their government? 


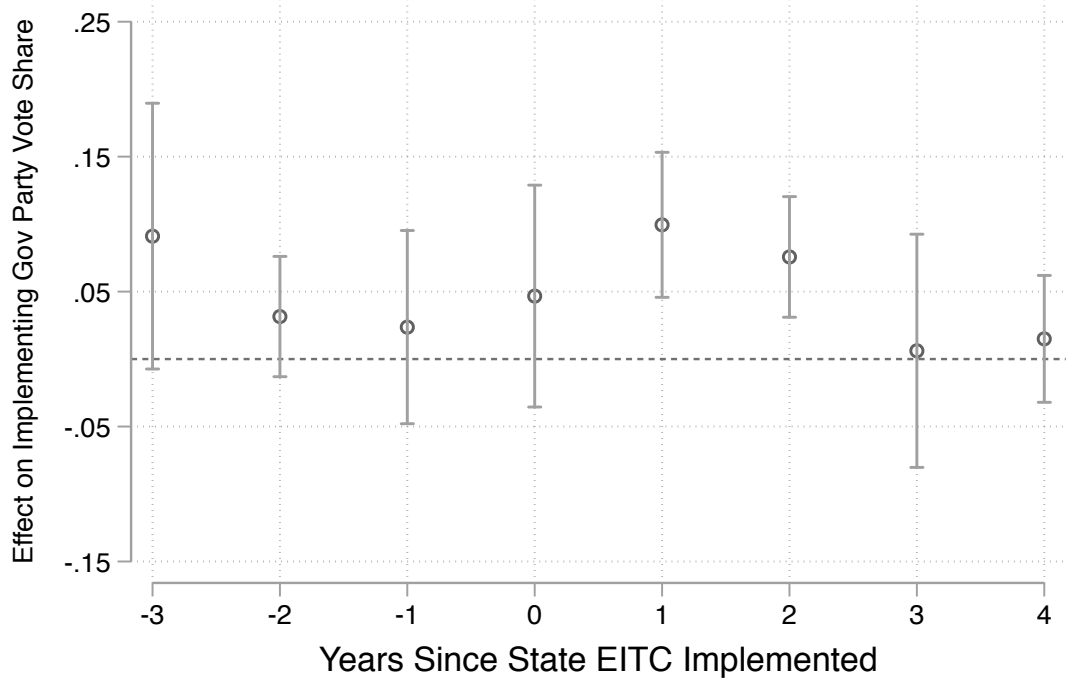

Figure 4 - Dynamic Effect of EITC on Implementing Governor Party's Vote Share The plot models the dynamic effect of the EITC program on the implementing Governor party's vote share. Year $=0$ is the year the state adopted the EITC program. Vertical lines indicate $95 \%$ confidence intervals using robust standard errors clustered by state. The plot shows that EITC programs might lead to an increase in the implementing party's vote share in the short term, but the effect dissipates by three years after the program's introduction.

In this section we show that individuals who benefit from EITC programs increase their approval for Governors after the program is implemented. Our main outcome of interest is a respondent's approval of her governor, which we code as a variable that ranges from 0 (strongly disapprove) to 1 (strongly approve). Using gubernatorial approval levels is an attractive dependent variable of interest for many reasons. Many scholars have shown that low income voters tend to participate less in politics than wealthier individuals (see, for example, Brady, Verba, and Schlozman (1995)). Our sample is no different. Table A.1 presents descriptive statistics on political participation for EITC-eligible individuals compared to the entire CCES sample for 2016. Survey respondents who were eligible for the EITC were less likely to self-report as having voted. Even if we presume individuals over-report their political participation on surveys, the difference between eligible and ineligible individuals is still significant and large. Additionally, approval levels allow us to not only understand how 
Table 3 - Effects of State EITC Expansion on Gubernatorial Approval Levels, County Level, 2008-2018

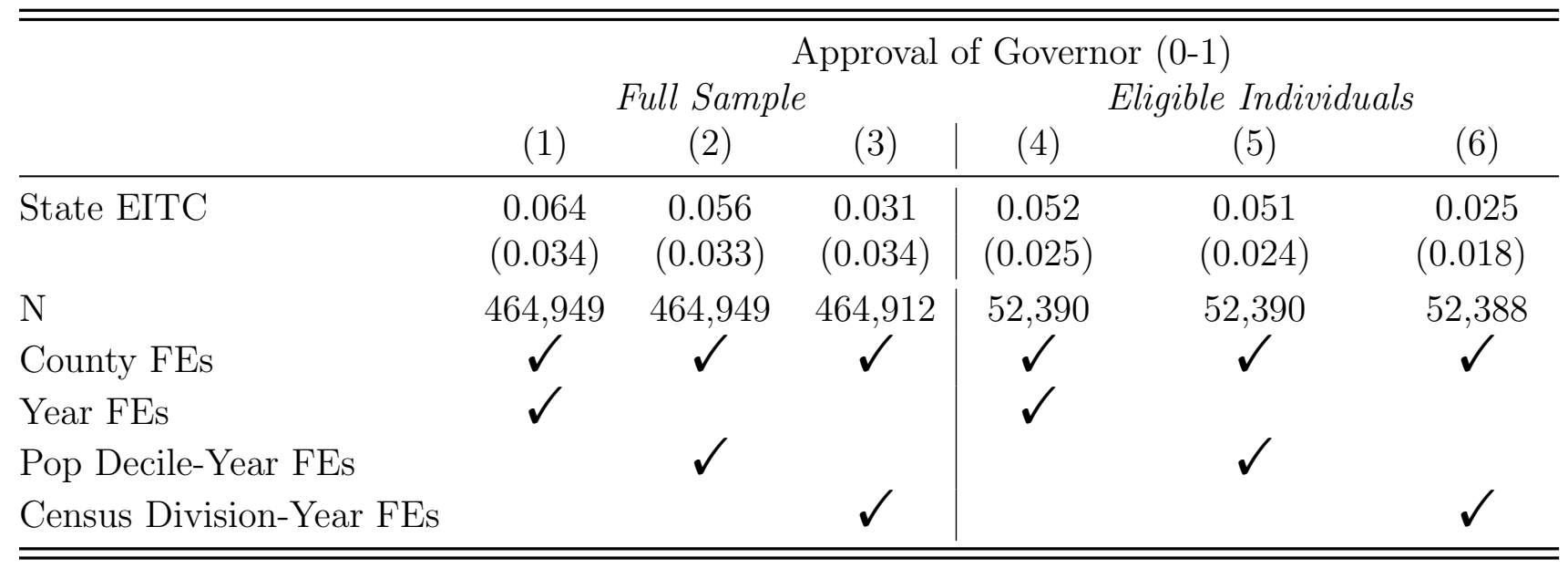

Robust standard errors clustered by state in parentheses. All specifications control for individuallevel characteristics, including gender, age, race, and level of education. Models (1) - (3) present results for the full sample. Models (4) - (6) present results for the sample of EITC-eligible individuals.

voters' sentiments about the government change in response to the EITC but they are also included annually in the survey and have a high response rate.

We first estimate the effect of state EITC roll-out on gubernatorial approval levels for the full sample of CCES respondents. Specifically, we estimate equations of the form:

$$
\text { Approval of } \text { Gov }_{i c t}=\alpha+\beta \text { State } \text { EITC }_{c t}+\gamma_{c}+\delta_{t}+\zeta X_{i}+\epsilon_{i c s t},
$$

where Approval of Gov $_{i c t}$ measures a given individual $i$ 's approval of the governor at time $t$ in county c, running from 0 to 1 . The variable State $E I T C_{c t}$ is an indicator variable for whether or not a state offers an EITC. Parameters $\gamma_{c}$ and $\delta_{t}$ stand in for county and year fixed effects, respectively. Finally $X_{i}$ is a vector of individual-level characteristics, including gender, age, race, and level of education. We also cluster standard errors at the state level for all of our specifications. As before, we relax the assumption of parallel trends in a variety of ways. The results do not change meaningfully, suggesting that the parallel trends assumption appears to hold. 
The first three columns of Table 3 presents estimates from three different specifications. We find that the introduction of a state-level EITC is associated with a .06 point increase in approval for governors overall. This finding alone implies that voters are responding positively to the introduction of the new credit, but this could be because individuals are reacting to an increased refund or because all voters approve of the governor's efficacy, in general. To distinguish between these explanations, we split our sample and look at the stated gubernatorial approval levels of EITC-eligible individuals, only. These results are shown in columns (4), (5), and (6) of Table 3. We still observe that approval levels increase among eligible individuals after the passage of a state EITC, however the magnitude of the effect is slightly smaller at 0.05 . In Appendix Table A.6, we show that these results are robust to the inclusion of controls for party identification and news interest, which we omit in the main text due to concerns that these variables may change post-treatment. The increase in ineligible individuals' approval scores could be attributed to a variety of explanations, including sociotropic effects or the general positive economic benefit of the EITC. We look into both of these options below.

\section{Individuals in Beneficiary Counties More Positive About their Gov- ernors}

Next, we investigate whether county context matters in how individuals evaluate the state EITC program. On the one hand, if individuals evaluate the benefits of a program sociotropically, we would expect that individuals in high exposure counties - counties that benefit the most from the program - should increase their approval of the governor more, regardless of their own individual eligibility. On the other hand, if individuals make evaluations of programs based on their own pocketbook compared to those of others around them, we would expect that in high exposure counties there would be divergence in approval for governors among eligible versus ineligible individuals. 
Table 4 - Heterogenous Effects of State EITC Expansion on Gubernatorial Approval Levels, County Level, 2008-2018

\begin{tabular}{|c|c|c|c|c|c|c|}
\hline & \multicolumn{6}{|c|}{ Approval of Governor (0-1) } \\
\hline & \multicolumn{2}{|c|}{ Full Sample } & \multicolumn{2}{|c|}{ Eligible Individuals } & \multirow{2}{*}{$\begin{array}{c}\text { Ineligible } \\
(5)\end{array}$} & \multirow{2}{*}{$\begin{array}{c}\text { Individuals } \\
\quad(6)\end{array}$} \\
\hline & (1) & $(2)$ & $(3)$ & (4) & & \\
\hline State EITC & $\begin{array}{c}0.064 \\
(0.034)\end{array}$ & $\begin{array}{c}0.065 \\
(0.035)\end{array}$ & $\begin{array}{c}0.052 \\
(0.025)\end{array}$ & $\begin{array}{c}0.035 \\
(0.027)\end{array}$ & $\begin{array}{c}0.064 \\
(0.035)\end{array}$ & $\begin{array}{c}0.067 \\
(0.036)\end{array}$ \\
\hline State EITC $\times$ High Exposure & & $\begin{array}{c}-0.003 \\
(0.003)\end{array}$ & & $\begin{array}{c}0.024 \\
(0.005)\end{array}$ & & $\begin{array}{l}-0.006 \\
(0.003)\end{array}$ \\
\hline $\mathrm{N}$ & 464,949 & 464,933 & 52,390 & 52,386 & 411,080 & 411,068 \\
\hline County FEs & $\sqrt{ }$ & $\sqrt{ }$ & $\sqrt{ }$ & $\sqrt{ }$ & $\sqrt{ }$ & $\sqrt{ }$ \\
\hline Year FEs & $\sqrt{ }$ & $\sqrt{ }$ & $\sqrt{ }$ & $\sqrt{ }$ & $\sqrt{ }$ & $\sqrt{ }$ \\
\hline
\end{tabular}

Robust standard errors clustered by state in parentheses. All specifications control for individuallevel characteristics, including gender, age, race, and level of education. Models (1) - (2) present results for the full CCES sample. Models (3) - (4) present results for the sample of EITC-eligible individuals. Models (5) - (6) present results for the sample of ineligible individuals.

To test between these explanations, we designate a county as being high exposure if its proportion of tax filers who claim the EITC is above the median - the same measure as in our county-level analyses. Again, because a tax payer's state EITC eligibility is linked to whether they are eligible for the federal EITC, this measure also approximates what fraction of individuals in a county are receiving the state EITC. Figure 5 plots the results. ElTC-eligible individuals in high exposure counties are more approving of their governors than those in low exposure counties. We observe no effect of state EITC implementation on credit-ineligible individuals, regardless of their county of residence.

This could indicate that eligible individuals in high exposure areas are more aware of the EITC as they and their neighbors regularly claim the credit or because taxpayer assistance programs, like those established through the Volunteer Income Tax Assistance program, are more likely to conduct outreach efforts in high exposure areas. These individuals are perhaps more likely to note the increase in their state tax refund and have an easier time attributing the change to the government compared to individuals in areas where few people claim the credit. While we have no way to test this, there is evidence that a reduction of social stigma 


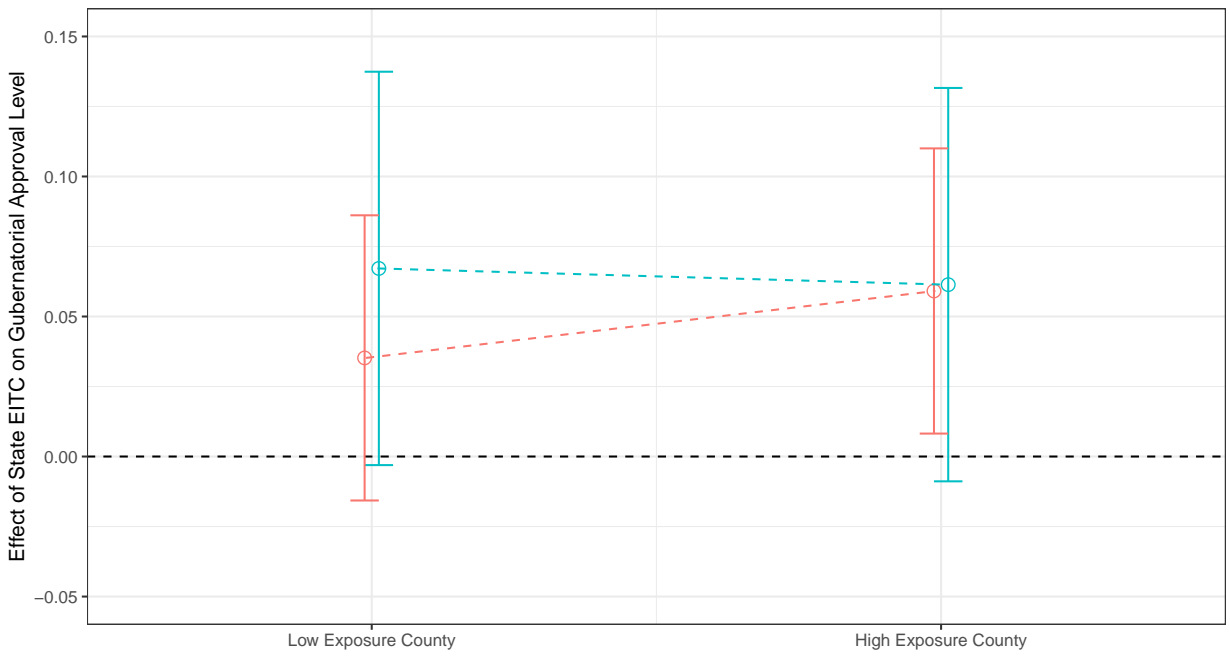

Figure 5 - Heterogenous Effects of State EITC on Gubernatorial Approval Levels The figure shows the interactive effect between state EITC implementation and whether or not the proportion of individuals in a county claiming the federal EITC is above the state median. The estimates in salmon present the results for our sample of eligible individuals and the estimates in teal present the results for our sample of ineligible individual. The regression includes county and year fixed effects. Vertical lines include $95 \%$ confidence intervals using robust standard errors clustered by state.

and an increase in uptake among peers is associated with increased participation in welfare programs. $^{27}$

One could argue that this result stems from eligible individuals in counties with more EITC claimants are more sensitive to the downstream economic effects of the EITC. If the EITC leads to more business spending, less unemployment, and more consumption, then we might expect that living in a high EITC-exposure county leads individuals to have a more positive outlook on the economy. To test this we analyze responses to the CCES question asking respondents whether the economy has improved in the past year. We dichotomize the variable such that a value of 1 indicates that a respondent felt the economy had improved and a value of 0 indicates that a respondent felt the economy had gotten worse.

The results for credit-eligible individuals are presented in Table 5. We show that individuals in high exposure counties feel more positively about the economy compared to other

\footnotetext{
${ }^{27}$ See Borjas and Hilton (1996); Bertrand, Luttmer, and Mullainathan (2000); Currie (2004), among others for evidence of this. Notably, scholarship on the role of network effects and stigma in uptake of the EITC has been inconclusive (e.g. Bhargava and Manoli (2015))
} 
Table 5 - Effects of State EITC Expansion on Perceptions of the Economy, 2008-2018

\begin{tabular}{|c|c|c|c|c|c|c|}
\hline & \multicolumn{6}{|c|}{ Perception of the Economy $(0-1)$} \\
\hline & (1) & $(2)$ & $(3)$ & $(4)$ & $(5)$ & $(6)$ \\
\hline State EITC & $\begin{array}{l}-0.036 \\
(0.034)\end{array}$ & $\begin{array}{l}-0.049 \\
(0.033)\end{array}$ & $\begin{array}{l}-0.021 \\
(0.034)\end{array}$ & $\begin{array}{l}-0.035 \\
(0.025)\end{array}$ & $\begin{array}{l}-0.052 \\
(0.024)\end{array}$ & $\begin{array}{c}-0.064 \\
(0.018)\end{array}$ \\
\hline State EITC $\times$ High Exposure & & $\begin{array}{c}0.019 \\
(0.010)\end{array}$ & & $\begin{array}{c}0.020 \\
(0.010)\end{array}$ & & $\begin{array}{c}0.018 \\
(0.011)\end{array}$ \\
\hline $\mathrm{N}$ & 48,810 & 48,806 & 48,810 & 48,806 & 48,734 & 48,730 \\
\hline County FEs & $\sqrt{ }$ & $\checkmark$ & $\checkmark$ & $\checkmark$ & $\sqrt{ }$ & $\sqrt{ }$ \\
\hline Year FEs & $\sqrt{ }$ & $\sqrt{ }$ & & & & \\
\hline Pop Decile-Year FEs & & & $\sqrt{ }$ & $\sqrt{ }$ & & \\
\hline Census Division-Year FEs & & & & & $\sqrt{ }$ & $\sqrt{ }$ \\
\hline
\end{tabular}

Robust standard errors clustered by state in parentheses. All specifications control for individuallevel characteristics, including gender, age, race, level of education, level of news interest, and party identification (3-point scale).

eligible individuals in low exposure counties, after the credit is implemented. ${ }^{28}$ However, the magnitude of this effect is relatively small and insufficient on its own to explain the results in Table 3.

\section{The Limited Temporal Effects of EITC-Passage}

In order to investigate the temporal effects of EITC-passage on the attitudes of beneficiaries, we employ the same lags and leads specification as our county-level analysis on our individuallevel data. Figure 6 suggests that the impact of the EITC on gubernatorial approval levels is limited to the year the credit is introduced. This finding perhaps explains why ShanksBooth and Mettler (2019) find no significant relationship between being an EITC recipient and sentiments towards the government. Based on our results, we would only expect to see a change in individuals' attitudes in their study in the first year of a new policy change. The fact that the authors only use data from 2008 to conduct their analysis - a year accompanied

\footnotetext{
${ }^{28}$ We also see that the main effect of state EITC implementation on perceptions of the economy is negative. This could be explained by states implementing expansionary fiscal policy, like the EITC, when the economy is relatively poor.
} 


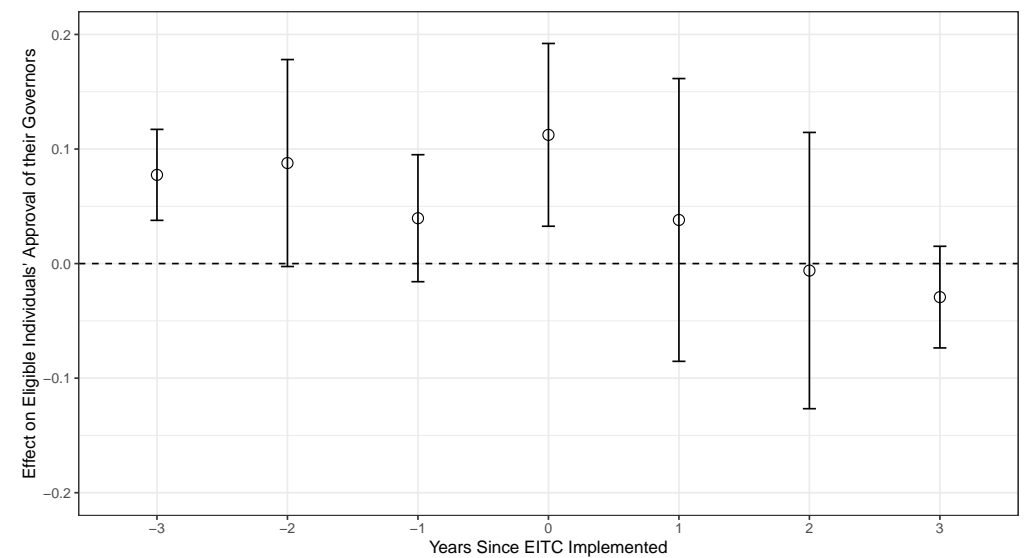

Figure 6 - Dynamic Effect of EITC on Eligible Individuals' Approval of Governor The figure shows the dynamic effect of EITC introduction on eligible individuals' gubernatorial approval levels with years since the introduction of the credit on the horizontal axis and survey respondents' opinions on the vertical axis. The regression includes county and population decile-year fixed effects. Vertical lines include 95\% confidence intervals using robust standard errors clustered by state.

by no major changes to the federal credit - and because the authors do not account for state variation implies they would likely find no difference.

\section{Voters Reward the Governor for State EITC Programs, But Not Other Officeholders}

We also assess the extent to which state-level EITCs affect individual approval for officeholders other than the governor. We look at credit-eligible individuals' approval of the president, the House member from their congressional district, and their Senators. The effect that we would expect is not obvious ex ante. On the one hand, if voters are accurately mapping the source of their tax refund to state-level politics, we would expect that individuals would not increase their support for the President or Congressional representatives. On the other hand, if voters update their beliefs about the government's efficacy more broadly, we would expect to see individuals reward other officeholders in the same way they reward their governors.

We present the results of the baseline specification in Table 6. State-level EITCs seem to be associated with lowered approval for the President and increased approval for Senators 
Table 6 - Effects of State EITC Expansion on Eligible Individuals' Approval Levels for Other Officeholders, 2008-2018.

\begin{tabular}{lccc}
\hline \hline & \multicolumn{3}{c}{ Approval of Officeholder $(0-1)$} \\
& (Presidential Approval) & (HM Approval) & (Senator Approval) \\
\hline State EITC & -0.063 & 0.014 & 0.036 \\
& $(0.018)$ & $(0.016)$ & $(0.014)$ \\
$\mathrm{N}$ & 52,626 & 35,686 & 29,725 \\
County FEs & $\boldsymbol{V}$ & $\boldsymbol{V}$ & $\sqrt{ }$ \\
Year FEs & $\boldsymbol{V}$ & $\boldsymbol{V}$ & $\sqrt{ }$ \\
\hline
\end{tabular}

Robust standard errors clustered by state in parentheses. All specifications control for individual-level characteristics, including gender, age, race, and level of education.

among eligible individuals. We find no effect of state-level EITCs on approval for House Representatives using this specification, nor any of our other specifications (shown in Appendix A.8).

We also look at the temporal effects of state EITC-passage on eligible individuals' approval levels for other officeholders. Figure 7 suggests that the results of the baseline specification are obfuscating the effects of the policy. Presidential approval levels appear to only increase three years after the passage of a state-level EITC, which could be attributable to noise. Further, while we cannot plausibly make the assumption of parallel trends in the case of Senatorial approval levels, the positive effect of a state EITC on eligible individuals' opinions is statistically indistinguishable from zero at the 5-percent significance level.

The above results indicate that state-EITC has a limited, if not null, effect on approval levels for other officeholders. Combined with the analysis on gubernatorial approval levels, the evidence suggests that eligible individuals are correctly attributing the state tax credit to state officials and not to federal officials.

\section{Summary}

Overall, the results in this section show that the introduction of state-level EITCs results in higher gubernatorial approval ratings among those who are eligible for the credit. This result 

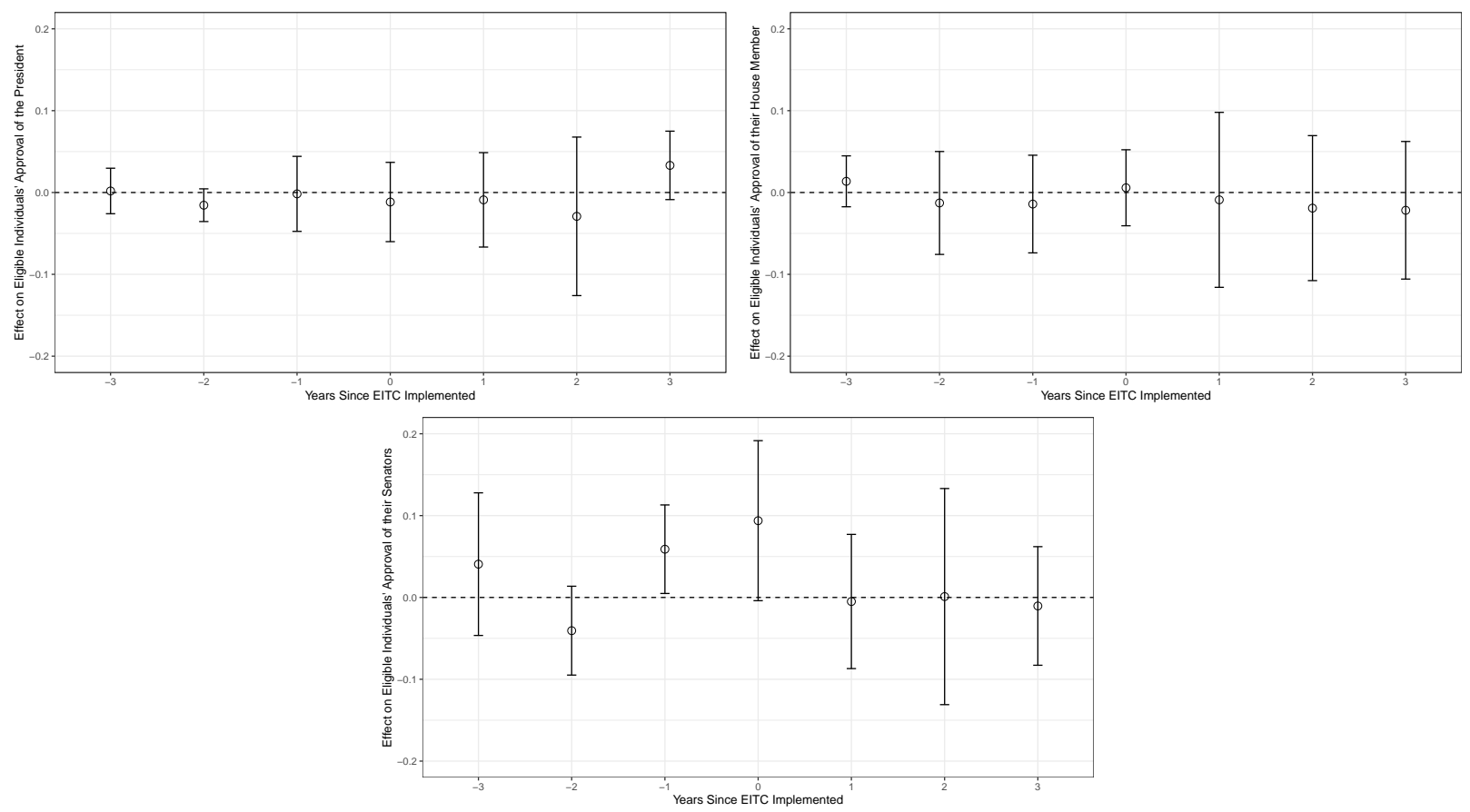

Figure 7 - Dynamic Effect of EITC on Eligible Individuals' Approval of Their Officeholders The figure shows the dynamic effect of EITC introduction on eligible individuals' approval levels with years since the introduction of the credit on the horizontal axis and survey respondents' opinions on the vertical axis. The regression includes county and year fixed effects as well as controls for respondent age, education, and race. Vertical lines include $95 \%$ confidence intervals using robust standard errors clustered by state.

is stronger in areas with more individuals claiming the credit. Eligible recipients increase their support for their incumbent Governor in response to the program's introduction, and they do not seem to increase their support for their incumbent President, US Senators, or US House representatives. This suggests that they are successfully able to map the introduction of the benefit they receive to the officeholder responsible for enacting it.

\section{Conclusion}

Whether and how voters translate their economic well-being to into political actions is a central inquiry of political economy research. In this paper, we explore the political effects of one of the most important social provision programs in the United States: the Earned Income Tax Credit (EITC). We assemble a county-level panel of gubernatorial election results and 
leverage the fact that states rolled out their own versions of the EITC over time to estimate the effects of the programs on elections. We find that state EITC programs, broadly, do not have large effects elections for Governor overall, but we do find some evidence that Republican governors are rewarded in the year after they enact the program. This pattern holds when making comparisons only among counties with similar populations, from similar regions, and with similar pre-treatment political trajectories.

The muted overall effects on elections, however, mask important individual-level dynamics of the program's effects. Turning to an individual-level, time-series cross-sectional design from CCES data, we find that individuals who are eligible for state EITC programs increase their support for the governors responsible for enacting the program after it is implemented. We also show that the program's beneficiaries reward the governor, but not other officeholders like the President, Senators, or US House Representatives, which suggests that voters are not only responsive political to receiving economic benefits from the government, but they are also attributing the credit to the officeholder responsible for implementing it.

Not only does this study contribute to the vast literature on economic voting, but it also speaks to work in policy feedback. Particularly, these results provide an important compliment to recent work analyzing the effects of the EITC and, more broadly, the study of "submerged" policies. Governors have an incentive to elevate the visibility of plausibly popular policies after implementation in an attempt to credit claim and reap electoral rewards before strategic party re-positioning (Stigler 1973) or voter myopia settles in (Tufte 1978). This study suggests promising avenues for future research asking when policies create new politics and how policy implementation matters. A body of work in public policy investigates how program administration and structure can impact benefit take-up and political participation (e.g., Soss 2002; Bruch, Ferree, and Soss 2010). Additionally, a number of recent studies in economics documents a positive relationship between tax credit knowledge and benefit take-up (Chetty and Saez 2013; Bhargava and Manoli 2015; Manoli and Turner 2016; Cranor, Kotb, and Goldin 2019). A natural extension of these inquiries and the present 
paper would be to investigate how government programs meant to increase policy take-up by lowering the costs of information acquisition, like the Volunteer Income Tax Assistance program or state EITC notification laws for employees, impact perceptions of government and voting behavior.

Finally, this paper emphasizes the positive side of political accountability: our results could be interpreted as individuals rewarding their governors for expanding their state's safety net. Much of the extant literature in American politics and beyond focuses on whether voters punish incumbents for misbehavior or poor economic conditions, whereas less work investigates what happens when incumbents pursue welfare-enhancing policies for their constituents. Indeed, in two of the best known studies on accountability, Key (1966) posits that "people vote only against, never for" and Campbell et al. (1960) argue that the average voter is "more likely to punish an incumbent party for its mistakes than reward it for its successes." Our study provides a useful contrast to that perspective and, in general, offers a promising avenue for future work investigating when voters reward their elected officials for economic policy. 


\section{References}

Achen, Christopher H, and Larry M Bartels. 2016. Democracy for Realists: Why Elections Do Not Produce Responsive Government. Princeton University Press.

Ansolabehere, Stephen, Marc Meredith, and Erik Snowberg. 2014. "Mecro-Economic Voting: Local Information and Micro-Perceptions of the Macro-Economy." Economics 83 Politics 26(3): 380-410.

Arceneaux, Kevin. 2006. "The Federal Face of Voting: Are Elected Officials Held Accountable for the Functions Relevant to Their Office?" Political Psychology 27(5): 731-754.

Arnold, R Douglas. 1990. The logic of congressional action. Yale University Press.

Ashworth, Scott, and Ethan Bueno De Mesquita. 2014. "Is Voter Competence Good for Voters?: Information, Rationality, and Democratic Performance." American Political Science Review 108(3): 565-587.

Averett, Susan, and Yang Wang. 2013. "The Effects of Earned Income Tax Credit Payment Expansion on Maternal Smoking." Health Economics 22(11): 1344-1359.

Baughman, Reagan A. 2005. "Evaluating the Impact of the Earned Income Tax Credit on Health Insurance Coverage." National Tax Journal pp. 665-684.

Baughman, Reagan A, and Noelia Duchovny. 2016. "State Earned Income Tax Credits and the Production of Child Health: Insurance Coverage, Utilization, and Health Status." National Tax Journal 69(1): 103.

Bertrand, Marianne, Erzo FP Luttmer, and Sendhil Mullainathan. 2000. "Network effects and welfare cultures." The Quarterly Journal of Economics 115(3): 1019-1055.

Bhargava, Saurabh, and Dayanand Manoli. 2015. "Psychological frictions and the incomplete take-up of social benefits: Evidence from an IRS field experiment." American Economic Review 105(11): 3489-3529.

Borjas, George J, and Lynette Hilton. 1996. "Immigration and the welfare state: Immigrant participation in means-tested entitlement programs." The quarterly journal of economics 111(2): 575-604.

Boyd-Swan, Casey, Chris M Herbst, John Ifcher, and Homa Zarghamee. 2016. "The Earned Income Tax Credit, Mental Health, and Happiness." Journal of Economic Behavior \&3 Organization 126: 18-38. 
Brady, Henry E, Sidney Verba, and Kay Lehman Schlozman. 1995. "Beyond SES: A resource model of political participation." American political science review 89(2): 271-294.

Bruch, Sarah K, Myra Marx Ferree, and Joe Soss. 2010. "From policy to polity: Democracy, paternalism, and the incorporation of disadvantaged citizens." American Sociological Review 75(2): 205-226.

Campbell, Andrea Louise. 2003. How policies make citizens: Senior political activism and the American welfare state. Princeton University Press.

Campbell, Angus, Philip Converse, Warren Miller, and Donald E Stokes. 1960. "The American Voter." Ann Arbor: University of Michigan Press .

Chetty, Raj, and Emmanuel Saez. 2013. "Teaching the tax code: Earnings responses to an experiment with EITC recipients." American Economic Journal: Applied Economics 5(1): $1-31$.

Clinton, Joshua D, and Michael W Sances. 2018. "The politics of policy: The initial mass political effects of medicaid expansion in the states." American Political Science Review 112(1): 167-185.

Cranor, Taylor, Sarah Kotb, and Jacob Goldin. 2019. "Evidence from EITC Notification Laws." National Tax Journal 72(2): 1-8.

Currie, Janet. 2004. The take up of social benefits. Technical report National Bureau of Economic Research.

de Benedictis-Kessner, Justin, and Christopher Warshaw. 2019. "Accountability for the Economy at All Levels of Government in United States Elections.".

Evans, William N, and Craig L Garthwaite. 2014. "Giving Mom a Break: The Impact of Higher EITC Payments on Maternal Health." American Economic Journal: Economic Policy 6(2): 258-90.

Fair, Ray C. 1978. "The Effect of Economic Events on Votes for President." The Review of Economics and Statistics 60(2): 159-173.

Feigenbaum, James, Alexander Hertel-Fernandez, and Vanessa Williamson. 2019. "From the Bargaining Table to the Ballot Box: Downstream Effects of Right-to-Work Laws." Working Paper. 
Green, Donald P, Bradley Palmquist, and Eric Schickler. 2004. Partisan Hearts and Minds: Political Parties and the Social Identities of Voters. Yale University Press.

Hall, Andrew B, Jesse Yoder, and Nishant Karandikar. 2019. "Economic Distress and Voting: Evidence from the Subprime Mortgage Crisis.".

Halpern-Meekin, Sarah, Kathryn Edin, Laura Tach, and Jennifer Sykes. 2015. It's Not Like I'm Poor: How Working Families Make Ends Meet in a Post-Welfare World. Univ of California Press.

Hamad, Rita, and David H Rehkopf. 2016. "Poverty and Child Development: A Longitudinal Study of the Impact of the Earned Income Tax Credit." American Journal of Epidemiology 183(9): 775-784.

Healy, Andrew J, Neil Malhotra, and Cecilia Hyunjung Mo. 2010. "Irrelevant Events Affect Voters' Evaluations of Government Performance." Proceedings of the National Academy of Sciences 107(29): 12804-12809.

Hopkins, Daniel J. 2018. The Increasingly United States: How and Why American Political Behavior Nationalized. University of Chicago Press.

Hoynes, Hilary, Doug Miller, and David Simon. 2015. "Income, The Earned Income Tax Credit, and Infant Health." American Economic Journal: Economic Policy 7(1): 172211.

Imai, Kosuke, Gary King, and Clayton Nall. 2009. "The Essential Role of Pair Matching in Cluster-Randomized Experiments, with Application to the Mexican Universal Health Insurance Evaluation." Statistical Science 24(1): 29-53.

Kettl, Donald F. 1988. "Performance and accountability: The challenge of government by proxy for public administration." The American Review of Public Administration 18(1): $9-28$.

Key, Valdimer Orlando. 1966. The Responsible Electorate: Rationality in Presidential Voting, 1936-1960. Harvard University Press.

Kleven, Henrik. 2019. "The EITC and the Extensive Margin: A Reappraisal." Working Paper .

Kogan, Vladimir. 2019. "Do Welfare Benefits Pay Electoral Dividends? Evidence from the National Food Stamp Program Rollout." Journal of Politics Forthcoming. 
Kramer, Gerald H. 1971. "Short-Term Fluctuations in US Voting Behavior, 1896-1964." American Political Science Review 65(1): 131-143.

Lenhart, Otto. 2019. "The Effects of Income on Health: New Evidence from the Earned Income Tax Credit." Review of Economics of the Household 17(2): 377-410.

Lerman, Amy E, and Katherine T McCabe. 2017. "Personal experience and public opinion: a theory and test of conditional policy feedback." The Journal of Politics 79(2): 624-641.

Liebman, Jeffrey B. 2000. "Who are the ineligible EITC recipients?" National Tax Journal pp. $1165-1185$.

Manoli, Day, and Nick Turner. 2016. "Do Notices Have Permanent Effects on Benefit Takeup." Tax L. Rev. 70: 439.

Margalit, Yotam. 2011. "Costly Jobs: Trade-Related Layoffs, Government Compensation, and Voting in US Elections." American Political Science Review 105(1): 166-188.

Markowitz, Sara, Kelli A Komro, Melvin D Livingston, Otto Lenhart, and Alexander C Wagenaar. 2017. "Effects of State-Level Earned Income Tax Credit Laws in the US on Maternal Health Behaviors and Infant Health Outcomes." Social Science \& Medicine 194: $67-75$.

Mettler, Suzanne. 2011. The submerged state: How invisible government policies undermine American democracy. University of Chicago Press.

Michener, Jamila D. 2017. "People, places, power: Medicaid concentration and local political participation." Journal of health politics, policy and law 42(5): 865-900.

Mullainathan, Sendhil, and Richard H Thaler. 2000. "Behavioral Economics." NBER Working Paper.

Rogers, Steven. 2017. "Electoral Accountability for State Legislative Roll Calls and Ideological Representation." American Political Science Review 111(3): 555-571.

Schattschneider, Elmer Eric et al. 1935. "Politics, pressures and the tariff.".

Shanks-Booth, Delphia, and Suzanne Mettler. 2019. "The Paradox of the Earned Income Tax Credit: Appreciating Benefits but not Their Source." Policy Studies Journal 47(2): 300-323.

Soss, Joe. 2002. Unwanted claims: The politics of participation in the US welfare system. University of Michigan Press. 
Stigler, George J. 1973. "General Economic Conditions and National Elections." The American Economic Review 63(2): 160-167.

Thompson, Daniel M. 2019. "Do Elections Increase Local Policy Responsiveness? Evidence from Elected Police Commissioners." Working Paper .

Tufte, Edward R. 1978. Political control of the economy. Princeton University Press. 


\section{Online Appendix}

Intended for online publication only.

\section{Contents}

A.1 Details about State EITC Programs and Data Used in the Analyses . . . 35

A.1.1 Geographic Distribution of State EITC Programs . . . . . . . . . 35

A.1.2 Characterizing EITC Recipients . . . . . . . . . . . . . 36

A.1.3 Questions Used in the CCES Analysis . . . . . . . . . . . . . 39

A.2 Additional County-Level Results . . . . . . . . . . . . . . . . . . . 41

A.2.1 Effect of State EITC Expansion on EITC Uptake . . . . . . . . . 41

A.2.2 Effect of State EITC Expansion on Turnout . . . . . . . . . . . . . 42

A.2.3 Effect of State EITC Expansion on Elections, by Implementing Party and Exposure . . . . . . . . . . . . . . . . . . . . . . . . . . . . . . . . 43

A.3 Additional Individual-level Results . . . . . . . . . . . . . . . . . . . 44

A.3.1 Effect of State EITC Expansion on Gubernatorial Approval Levels, additional controls . . . . . . . . . . . . . . . . . . 44

A.3.2 Effect of State EITC Expansion on Attitudes Towards the Economy, Credit-Ineligible Individuals . . . . . . . . . . . . . . . . . 45

A.3.3 Effect of State EITC on Eligible Individuals' Approval of Other Officeholders .................... . . 46 


\section{A.1 Details about State EITC Programs and Data Used in the Analyses}

\section{A.1.1 Geographic Distribution of State EITC Programs}

Figure A.1 shows the states that implemented its own Earned Income Tax Credit program as of 2016. States in dark blue had refundable credits, meaning individuals observe the credit in the form of a state tax refund. States in light blue - Delaware, Ohio, and Virginia - had state EITC programs in the form of non-refundable credits. Most of the states with EITC programs are concentrated in the Northeast, the Midwest, and the West Coast. Few states in the South, where a a larger fraction of tax filers claim the EITC (see Figure 1) have their own state EITC programs.

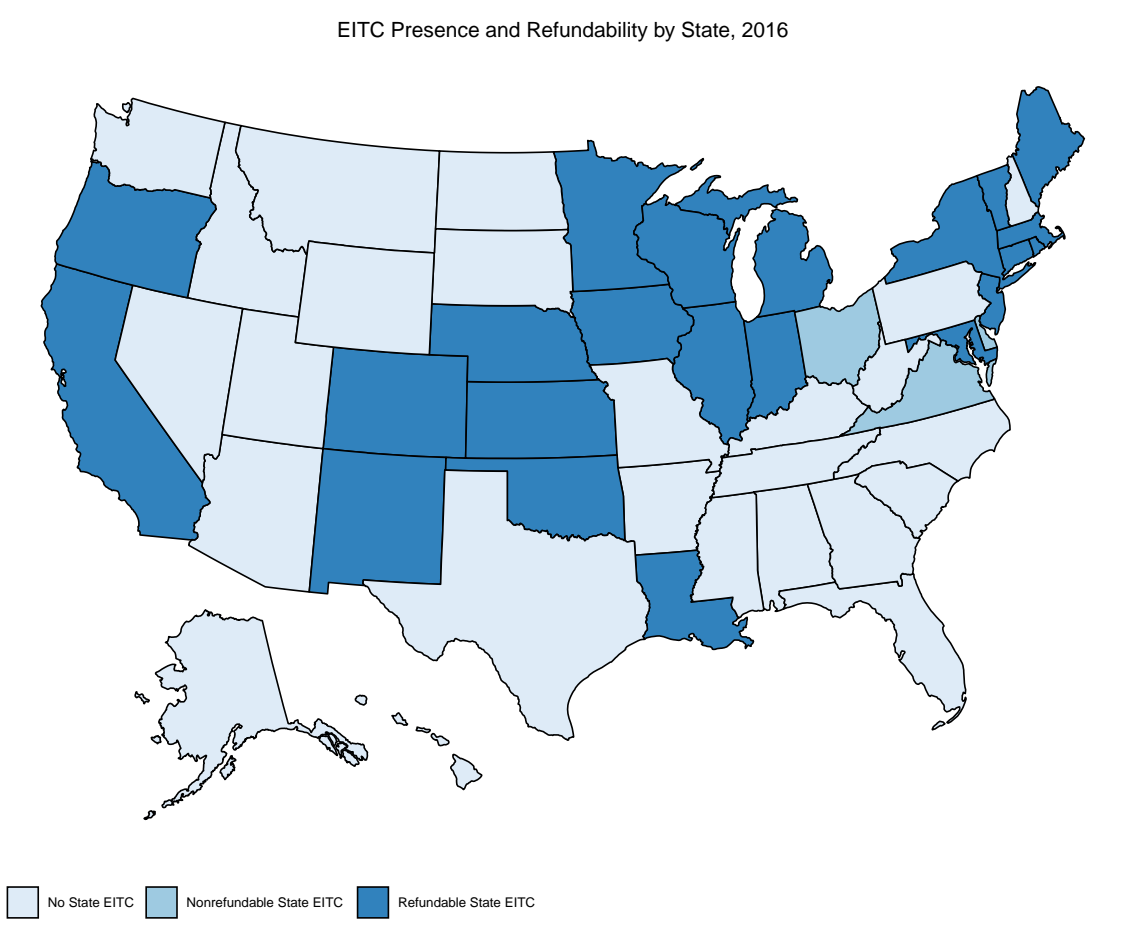

Figure A.1 - Geographic Distribution of State EITC Programs, 2016 The darkest blue indicates a refundable state EITC program. The next darkest blue indicates the presence of a state EITC program that has nonrefundable credits (Delaware, Ohio, and Virginia). The lightest blue indicates no state EITC program. 
A.1.2 Characterizing EITC Recipients 


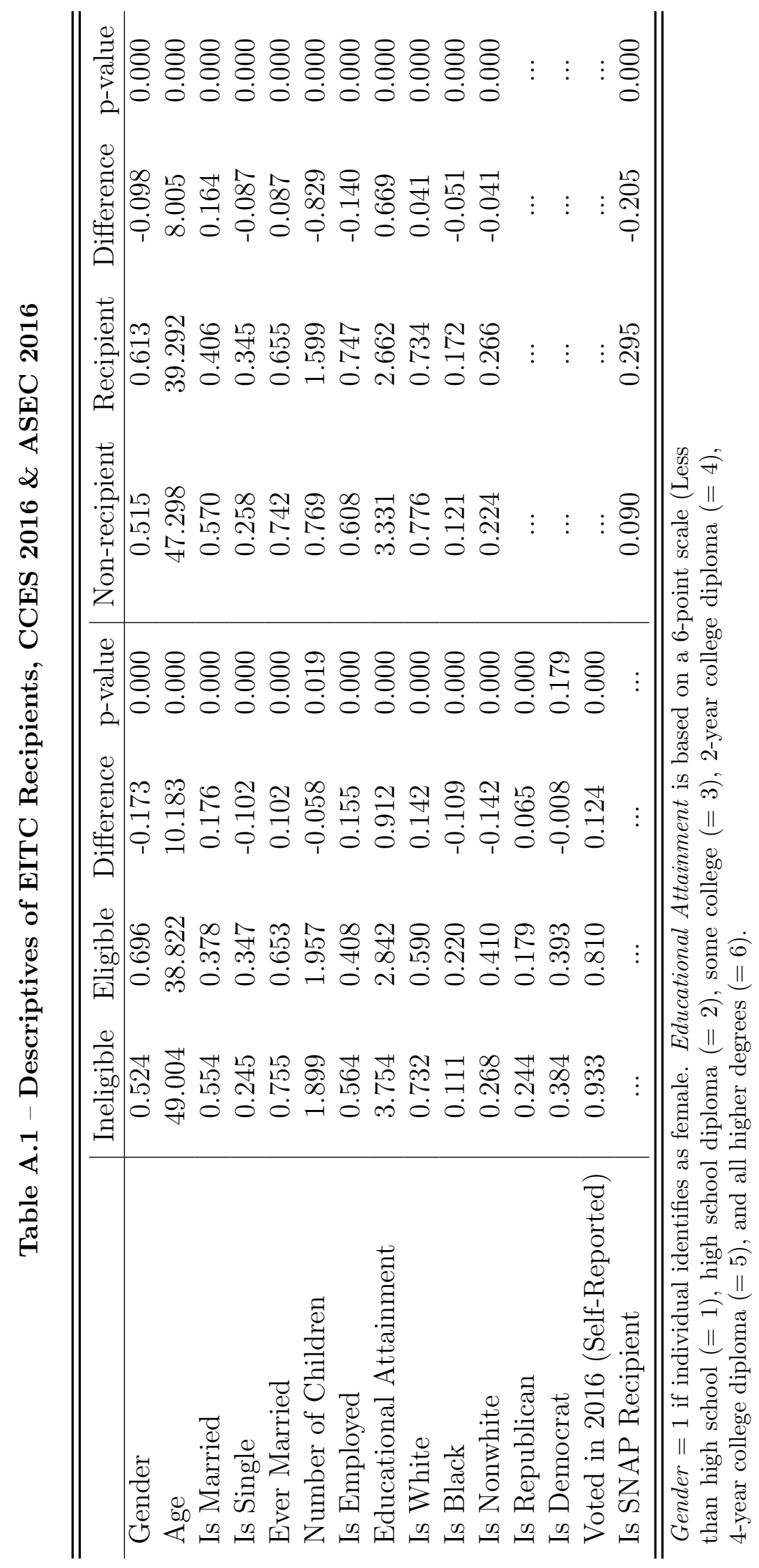


Table A.2 - Comparing EITC Recipients, ASEC and CCES 2016

\begin{tabular}{lcccc}
\hline \hline & ASEC & CCES & Difference & p-value \\
\hline Gender & 0.613 & 0.696 & -0.083 & 0.000 \\
Age & 39.292 & 38.822 & 0.471 & 0.010 \\
Is Married & 0.406 & 0.378 & 0.028 & 0.000 \\
Is Single & 0.345 & 0.347 & -0.002 & 0.721 \\
Ever Married & 0.655 & 0.653 & 0.002 & 0.721 \\
Number of Children & 1.599 & 1.957 & -0.358 & 0.000 \\
Is Employed & 0.747 & 0.408 & 0.339 & 0.000 \\
Educational Attainment & 2.662 & 2.842 & -0.180 & 0.000 \\
Is White & 0.734 & 0.590 & 0.145 & 0.000 \\
Is Black & 0.172 & 0.220 & -0.048 & 0.000 \\
\hline \hline
\end{tabular}

Table depicts results of a difference in means analysis comparing the characteristics of the ASEC and CCES samples. Gender $=1$ if individual identifies as female. Educational Attainment is based on a 6-point scale (Less than high school $(=1)$, high school diploma $(=2)$, some college $(=3)$, 2-year college diploma $(=4)$, 4-year college diploma $(=5)$, and all higher degrees $(=6)$. The CCES sample we use is younger and more female. Additionally, on average respondents have more children, are less likely to be employed, and are more educated. 


\section{A.1.3 Questions Used in the CCES Analysis}

\section{Gubernatorial Approval Analysis}

"Do you approve of the way each is doing their job... Governor of [Pipe State]"

\begin{tabular}{lc}
\hline & $\mathrm{n}$ \\
\hline Strongly Disapprove & 125,236 \\
Disapprove & 9,247 \\
Somewhat Disapprove & 82,019 \\
Not Sure & 26,072 \\
Somewhat Approve & 138,405 \\
Approve & 14,319 \\
Strongly Approve & 70,900 \\
\hline
\end{tabular}

Economic Approval Analysis

"Over the past year the nation's economy has ...?"

\begin{tabular}{cc}
\hline & $\mathrm{n}$ \\
\hline Gotten Better & 131,038 \\
Gotten Worse & 336,268 \\
\hline
\end{tabular}

"Gotten better" includes all responses where the respondent felt the economy had improved, including: "Gotten better", "Gotten much better", "Gotten somewhat better", "Much better", and "Somewhat better."

\section{Federal-Level Officeholder Approval Analysis}

"Do you approve of the way each is doing their job... [Pipe Incumbent President]"

\begin{tabular}{lc}
\hline & $\mathrm{n}$ \\
\hline Strongly Disapprove & 207,309 \\
Disapprove & 5,574 \\
Somewhat Disapprove & 47,390 \\
Not Sure & 14,940 \\
Somewhat Approve & 101,065 \\
Approve & 11,426 \\
Strongly Approve & 101,491 \\
\hline
\end{tabular}


"Do you approve of the way each is doing their job... [Pipe Incumbent Representative's Name]"

\begin{tabular}{lc}
\hline & $\mathrm{n}$ \\
\hline Strongly Disapprove & 60,281 \\
Disapprove & 69,899 \\
Somewhat Disapprove & 6,732 \\
Not Sure & 35,915 \\
Somewhat Approve & 13,800 \\
Approve & 121,324 \\
Strongly Approve & 53,680 \\
\hline
\end{tabular}

"Do you approve of the way each is doing their job... [Pipe Incumbent Senator 1's Name]"

\begin{tabular}{lc}
\hline & $\mathrm{n}$ \\
\hline Strongly Disapprove & 78,024 \\
Disapprove & 78,967 \\
Somewhat Disapprove & 8,313 \\
Not Sure & 32,926 \\
Somewhat Approve & 14,739 \\
Approve & 120,838 \\
Strongly Approve & 46,444 \\
\hline
\end{tabular}

"Do you approve of the way each is doing their job.... [Pipe Incumbent Senator 2's Name]"

\begin{tabular}{lc}
\hline & $\mathrm{n}$ \\
\hline Strongly Disapprove & 33,743 \\
Disapprove & 60,833 \\
Somewhat Disapprove & 6,554 \\
Not Sure & 41,872 \\
Somewhat Approve & 13,078 \\
Approve & 92,986 \\
Strongly Approve & 42,699 \\
\hline
\end{tabular}




\section{A.2 Additional County-Level Results}

\section{A.2.1 Effect of State EITC Expansion on EITC Uptake}

Table A.3 shows the effect of state EITC programs on the number of tax filers who claim the EITC (column 1) and the proportion of tax filers who claim the EITC (column 2). Implementing a state EITC program does not seem to lead to an increase in either of these outcome variables measuring uptake. For example, state EITC expansion leads to a small decrease in the number of EITC claims - about 23 fewer claims, which is negligible as a fraction of the average number of EITC claims in a county-year, which is over 10,000. We can also comfortably rule out large effects: the standard error in column 1 is about 325 claims. In column 2 , we find the expansion leads to a decline in in the percent of filers to claim the EITC by about 0.002 percentage points. The $95 \%$ confidence interval for the effect size ranges from -0.58 percentage points to about +0.58 percentage points, so again we can rule out large effects of state EITC programs on EITC uptake.

Table A.3 - Effect of State EITC Expansion on EITC Uptake, 2004-2016.

\begin{tabular}{lcc}
\hline \hline & Num EITC Claims & Pct EITC Claims \\
& $(1)$ & $(2)$ \\
\hline State EITC Expansion & -23.48 & -0.002 \\
& $(325.88)$ & $(0.291)$ \\
$\mathrm{N}$ & 37,015 & 37,015 \\
\# States & 51 & 51 \\
Outcome Mean & 10,872 & 20.47 \\
County FEs & $\mathrm{Y}$ & $\mathrm{Y}$ \\
Year FEs & $\mathrm{Y}$ & $\mathrm{Y}$ \\
\hline \hline
\end{tabular}

Robust standard errors clustered by state in parentheses. The outcome in column 1 is the number of EITC claims in a county, and the outcome in column 2 is the proportion of tax filers in a given county that claim the EITC, which is coded from 0 to 100. 


\section{A.2.2 Effect of State EITC Expansion on Turnout}

In this section, we estimate the effect of state EITC expansion on the county's turnout. In columns 1 through 3 we present three different specifications, similar to the first three columns of Table 2 in the main text, and we find do not find evidence that the programs affected turnout. In columns 4 through 6 , we interact the state EITC treatment with our measure of a county's exposure to the program, as we detail in section 3. Again, we do not find evidence that state EITC programs affected turnout for either low or high exposure counties.

Table A.4 - Effects of State EITC Expansion on Turnout in Gubernatorial Elections, County Level, 2002-2018.

\begin{tabular}{lcccccc}
\hline \hline & & \multicolumn{5}{c}{$\log ($ Total Votes $)$} \\
& $(1)$ & $(2)$ & $(3)$ & $(5)$ & $(5)$ & $(6)$ \\
\hline State EITC & -0.12 & -0.13 & -0.01 & -0.13 & -0.13 & 0.01 \\
& $(0.05)$ & $(0.05)$ & $(0.04)$ & $(0.06)$ & $(0.05)$ & $(0.04)$ \\
State EITC $\times$ High Exposure & & & & 0.02 & 0.02 & -0.07 \\
& & & & $(0.06)$ & $(0.05)$ & $(0.04)$ \\
N & 23,533 & 23,302 & 23,533 & 23,048 & 23,048 & 23,048 \\
County FEs & $\mathrm{Y}$ & $\mathrm{Y}$ & $\mathrm{Y}$ & $\mathrm{Y}$ & $\mathrm{Y}$ & $\mathrm{Y}$ \\
Year FEs & $\mathrm{Y}$ & $\mathrm{N}$ & $\mathrm{N}$ & $\mathrm{Y}$ & $\mathrm{N}$ & $\mathrm{N}$ \\
Pop Decile-Year FEs & $\mathrm{N}$ & $\mathrm{Y}$ & $\mathrm{N}$ & $\mathrm{N}$ & $\mathrm{Y}$ & $\mathrm{N}$ \\
Census Division-Year FEs & $\mathrm{N}$ & $\mathrm{N}$ & $\mathrm{Y}$ & $\mathrm{N}$ & $\mathrm{N}$ & $\mathrm{Y}$ \\
\hline \hline
\end{tabular}

Robust standard errors clustered by state in parentheses. 


\section{A.2.3 Effect of State EITC Expansion on Elections, by Imple- menting Party and Exposure}

In Table A.5 we show the full results of the effects of state EITC expansion on county-level election results for Governor. The columns mirror the specifications in Table 2, which we justify in the main text in section 3 . We use the coefficients and standard errors from column 4, our preferred specification that estimates the difference-in-differences using only variation within pairs matched based on their pre-treatment trends in vote shares, to generate the coefficient plot in Figure 3.

Table A.5 - Effects of State EITC Expansion on Gubernatorial Elections by Exposure to EITC, County Level, 2002-2018.

\begin{tabular}{lcccc}
\hline \hline & \multicolumn{3}{c}{ Dem Gov Vote Pct $(0-1)$} \\
& $(1)$ & $(2)$ & $(3)$ & $(4)$ \\
\hline State EITC & -0.01 & -0.01 & -0.01 & -0.04 \\
& $(0.03)$ & $(0.02)$ & $(0.03)$ & $(0.03)$ \\
State EITC $\times$ Implemented by Dem & 0.03 & 0.01 & 0.02 & 0.06 \\
& $(0.02)$ & $(0.02)$ & $(0.03)$ & $(0.04)$ \\
State EITC $\times$ High Exposure & -0.02 & -0.04 & -0.01 & -0.02 \\
& $(0.03)$ & $(0.03)$ & $(0.02)$ & $(0.04)$ \\
State EITC $\times$ Implemented by Dem Highosure & 0.01 & 0.03 & -0.02 & 0.01 \\
& $(0.03)$ & $(0.03)$ & $(0.02)$ & $(0.04)$ \\
N Explar & 14,463 & 14,463 & 14,463 & 8,986 \\
County FEs & $\mathrm{Y}$ & $\mathrm{Y}$ & $\mathrm{Y}$ & $\mathrm{Y}$ \\
Year FEs & $\mathrm{Y}$ & $\mathrm{N}$ & $\mathrm{N}$ & $\mathrm{N}$ \\
Pop Decile-Year FEs & $\mathrm{N}$ & $\mathrm{Y}$ & $\mathrm{N}$ & $\mathrm{N}$ \\
Census Division-Year FEs & $\mathrm{N}$ & $\mathrm{N}$ & $\mathrm{Y}$ & $\mathrm{N}$ \\
Pre Trend Match-Year FEs & $\mathrm{N}$ & $\mathrm{N}$ & $\mathrm{N}$ & $\mathrm{Y}$ \\
Population Weights & $\mathrm{Y}$ & $\mathrm{Y}$ & $\mathrm{Y}$ & $\mathrm{Y}$ \\
\hline \hline Robut & &
\end{tabular}

Robust standard errors clustered by state in parentheses. Implementing Party is 1 for Dem, - 1 for Rep. High Exposure is a dummy variable for whether the county is above the median in terms of the proportion of tax filers who claim the EITC. Main effects for lower order terms are absorbed by fixed effects. 


\section{A.3 Additional Individual-level Results}

\section{A.3.1 Effect of State EITC Expansion on Gubernatorial Approval Levels, additional controls}

In Table A.6 we show the results of the effects of state EITC expansion on individual-level approval for Governor with additional individual-level controls. The columns mirror the specifications in Table 3.

Table A.6 - Effects of State EITC Expansion on Gubernatorial Approval Levels, County Level, 2008-2018

\begin{tabular}{lccc|ccc}
\hline \hline & \multicolumn{5}{c}{ Approval of Governor (0-1) } \\
& $(1)$ & $(2)$ & $(3)$ & $(4)$ & $(5)$ & $(6)$ \\
\hline State EITC & 0.065 & 0.057 & 0.030 & 0.052 & 0.050 & 0.024 \\
& $(0.034)$ & $(0.033)$ & $(0.035)$ & $(0.024)$ & $(0.023)$ & $(0.019)$ \\
N & 451,791 & 451,791 & 451,754 & 48,584 & 48,584 & 48,582 \\
County FEs & $\checkmark$ & $\checkmark$ & $\checkmark$ & $\checkmark$ & $\checkmark$ & $\checkmark$ \\
Year FEs & $\checkmark$ & & & $\checkmark$ & & $\checkmark$ \\
Pop Decile-Year FEs & & $\checkmark$ & & & & $\checkmark$ \\
Census Division-Year FEs & & & $\checkmark$ & & & $\checkmark$ \\
\hline \hline
\end{tabular}

Robust standard errors clustered by state in parentheses. All specifications control for individuallevel characteristics, including gender, age, race, level of education, level of news interest, and party identification (3-point scale). Models (1) - (3) present results for the full sample. Models (4) - (6) present results for the sample of EITC-eligible individuals. 


\section{A.3.2 Effect of State EITC Expansion on Attitudes Towards the Economy, Credit-Ineligible Individuals}

In Table A.7 we show the effect of state EITC implementation on attitudes for the economy for those that are ineligible for the credit. The columns mirror the specification in Table 5.

Table A.7 - Effects of State EITC Expansion on Perceptions of the Economy, Credit-Ineligible Individuals, 2008-2018

\begin{tabular}{|c|c|c|c|c|c|c|}
\hline & \multicolumn{6}{|c|}{ Perception of the Economy $(0-1)$} \\
\hline & (1) & $(2)$ & $(3)$ & $(4)$ & $(5)$ & (6) \\
\hline State EITC & $\begin{array}{l}-0.028 \\
(0.011)\end{array}$ & $\begin{array}{c}-0.044 \\
(0.013)\end{array}$ & $\begin{array}{c}-0.014 \\
(0.009)\end{array}$ & $\begin{array}{c}-0.031 \\
(0.010)\end{array}$ & $\begin{array}{l}-0.021 \\
(0.007)\end{array}$ & $\begin{array}{l}-0.039 \\
(0.007)\end{array}$ \\
\hline State EITC $\times$ High Exposure & & $\begin{array}{c}0.030 \\
(0.005)\end{array}$ & & $\begin{array}{c}0.031 \\
(0.005)\end{array}$ & & $\begin{array}{c}0.034 \\
(0.004)\end{array}$ \\
\hline $\mathrm{N}$ & 404,207 & 404,195 & 404,207 & 404,195 & 403,374 & 403,362 \\
\hline County FEs & $\sqrt{ }$ & $\sqrt{ }$ & $\sqrt{ }$ & $\sqrt{ }$ & $\sqrt{ }$ & $\sqrt{ }$ \\
\hline Year FEs & $\sqrt{ }$ & $\sqrt{ }$ & & & & \\
\hline Pop Decile-Year FEs & & & $\sqrt{ }$ & $\sqrt{ }$ & & \\
\hline Census Division-Year FEs & & & & & $\sqrt{ }$ & $\sqrt{ }$ \\
\hline
\end{tabular}

Robust standard errors clustered by state in parentheses. All specifications control for individuallevel characteristics, including gender, age, race, level of education, level of news interest, and party identification (3-point scale). 


\section{A.3.3 Effect of State EITC on Eligible Individuals' Approval of Other Officeholders}

In Table A.8 we show alternative fixed-effect specifications for the results shown in Table 6.

Table A.8 - Effects of State EITC Expansion on Federal Officeholder Approval Levels, 2008-2018

\begin{tabular}{|c|c|c|c|c|c|c|}
\hline & \multicolumn{6}{|c|}{ Approval of Other Office Holders (0-1) } \\
\hline & \multirow{2}{*}{\multicolumn{2}{|c|}{$\begin{array}{c}\text { President Approval } \\
(1)\end{array}$}} & \multicolumn{2}{|c|}{ HM Approval } & \multicolumn{2}{|c|}{ Senator Approval } \\
\hline & & & $(3)$ & $(4)$ & $(5)$ & $(6)$ \\
\hline State EITC & $\begin{array}{l}-0.027 \\
(0.012)\end{array}$ & $\begin{array}{l}-0.062 \\
(0.013)\end{array}$ & $\begin{array}{c}0.014 \\
(0.017)\end{array}$ & $\begin{array}{l}-0.025 \\
(0.019)\end{array}$ & $\begin{array}{c}0.041 \\
(0.014)\end{array}$ & $\begin{array}{c}0.011 \\
(0.013)\end{array}$ \\
\hline $\mathrm{N}$ & 52,626 & 52,547 & 35,686 & 35,635 & 29,725 & 29,723 \\
\hline County FEs & $\sqrt{ }$ & $\sqrt{ }$ & $\sqrt{ }$ & $\sqrt{ }$ & $\sqrt{ }$ & $\sqrt{ }$ \\
\hline Pop Decile-Year FEs & $\sqrt{ }$ & & $\sqrt{ }$ & & $\sqrt{ }$ & \\
\hline Census Division-Year FEs & & $\sqrt{ }$ & & $\sqrt{ }$ & & $\sqrt{ }$ \\
\hline
\end{tabular}

Robust standard errors clustered by state in parentheses. All specifications control for individuallevel characteristics, including gender, age, race, and level of education. 